\title{
snoRNPs: Functions in Ribosome Biogenesis
}

\author{
Sandeep Ojha ${ }^{1}$, Sulochan Malla ${ }^{1}$ and Shawn M. Lyons ${ }^{1,2, *(\mathbb{D})}$ \\ 1 Department of Biochemistry, Boston University School of Medicine, Boston, MA 02115, USA; \\ sojha@bu.edu (S.O.); smalla2012@my.fau.edu (S.M.) \\ 2 The Genome Science Institute, Boston University School of Medicine, Boston, MA 02115, USA \\ * Correspondence: smlyons1@bu.edu; Tel.: +1-617-358-4280
}

Received: 20 April 2020; Accepted: 13 May 2020; Published: 18 May 2020

Abstract: Ribosomes are perhaps the most critical macromolecular machine as they are tasked with carrying out protein synthesis in cells. They are incredibly complex structures composed of protein components and heavily chemically modified RNAs. The task of assembling mature ribosomes from their component parts consumes a massive amount of energy and requires greater than 200 assembly factors. Among the most critical of these are small nucleolar ribonucleoproteins (snoRNPs). These are small RNAs complexed with diverse sets of proteins. As suggested by their name, they localize to the nucleolus, the site of ribosome biogenesis. There, they facilitate multiple roles in ribosomes biogenesis, such as pseudouridylation and 2'-O-methylation of ribosomal (r)RNA, guiding pre-rRNA processing, and acting as molecular chaperones. Here, we reviewed their activity in promoting the assembly of ribosomes in eukaryotes with regards to chemical modification and pre-rRNA processing.

Keywords: snoRNA; snoRNP; ribosome biogenesis; pseudouridylation; 2'-O-methylation; RNA processing

\section{Introduction}

Chemical modifications of RNA are found throughout all domains of life. The MODOMICS database currently lists 172 experimentally confirmed RNA modifications [1], although recent data suggests that there could be other unclassified RNA modifications [2]. Recent advances have begun to shed light on the role of RNA modifications in messenger (m)RNA, yet the most heavily modified cellular RNAs are transfer (t)RNAs and ribosomal (r)RNAs. Combined, these two classes comprise more than $90 \%$ of all cellular RNA, so the relative importance of RNA modification on these molecules cannot be understated. Modifications of rRNA are widespread throughout all domains of life [3,4]. Ribosomes are incredibly complex macromolecular machines comprised of 80 proteinaceous components and four noncoding RNAs (5S, 5.8S, 18S, and 25S/28S rRNA). Biogenesis of ribosomes is meticulously regulated by integrating translation of ribosomal proteins; transcription, processing and modification of rRNAs; and assembly of these components.

Within rRNAs, the vast majority of modifications are either pseudouridylation ( $\Psi)$ or $2^{\prime}$-O-methylation (2'Ome) whose deposition is most commonly facilitated by small nucleolar ribonucleoproteins (snoRNPs). In addition to guiding the deposition of these modifications, certain snoRNPs have critical roles in the regulation the processing and maturation of rRNAs. Further integrating their role in ribosome biogenesis, many snoRNAs, the RNA component of snoRNPs, are found within the introns of ribosomal proteins or ribosome biogenesis factors. In this review, we will discuss the biogenesis of snoRNPs and their role in directing ribosome assembly.

\section{Structure and Components}

Generally, snoRNPs come in two major classes: Box C/D and Box H/ACA. Although, there are non-canonical snoRNPs, such as RMRP, that have critical roles in ribosome biogenesis, or TERC, 
which aids in maintenance of telomeres. Regardless of the class, each snoRNP is composed of a snoRNA and an assemblage of proteins. The nomenclature denoting each class of snoRNP is derived from conserved sequence elements within each snoRNA.

\subsection{Box C/D snoRNAs}

Box C/D snoRNPs catalyze the methylation of the 2' hydroxyl group of ribose in RNA (Figure 1A) [5]. The RNA component of these, Box C/D snoRNAs, shares two sets of conserved sequence motifs: Box C (RUGAUGA) and Box D (CUGA) (Figure 1B). The U3 (SNORD3) snoRNA was the first to be fully characterized (discussed below). Analysis of U3 snoRNAs from humans, Xenopus laevis, Xenopus borealis, Rattus rattus, Saccharomyces cerevisiae, Schizosaccharomyces pombe, and Dictyostelium revealed the conservation of Box C and Box D [6-8]. But, it was only after the characterization of the U8 (SNORD118) and U13 (SNORD13) snoRNAs that it was appreciated that these belonged to a distinct class of small RNAs [9]. Box $C$ and Box D exist in pairs on a single molecule, called Box $C / C^{\prime}$ and Box $\mathrm{D} / \mathrm{D}^{\prime}$, with the $\mathrm{C}^{\prime}$ and $\mathrm{D}^{\prime}$ boxes being more degenerate. Structurally, Box $\mathrm{C} / \mathrm{D}$ snoRNAs are hairpins containing a large internal loop, bounded by the Box $C / \mathrm{C}^{\prime}$ and Box $\mathrm{D} / \mathrm{D}^{\prime}$ motifs. Box $\mathrm{C}$ and $\mathrm{D}$ can base-pair with each other forming stem-bulge-stem structure called a "kink-turn" or "K-turn" motif.

A

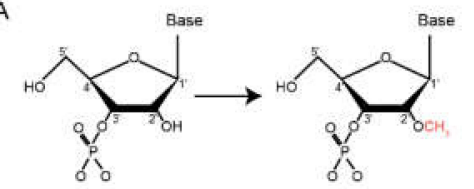

C

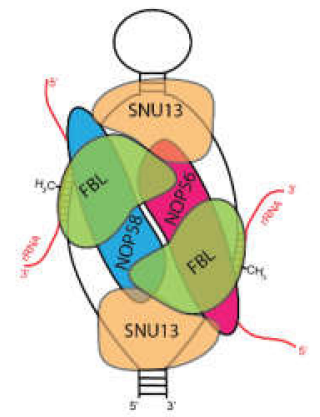

B

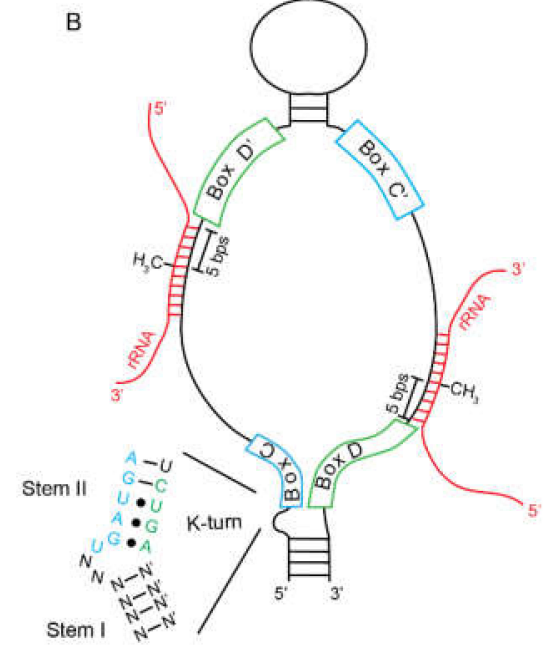

Figure 1. Box C/D snoRNPs. (A) Box C/D snoRNPs catalyze the methylation of the 2 ' hydroxyl of RNA. This is thought to reduce the hydrophilic nature of the nucleotides and allow rRNA to be buried inside of the ribosome. (B) Secondary structure of a typical Box C/D snoRNA indicating the location of Box $\mathrm{C} / \mathrm{C}^{\prime}$ (blue), Box D/D' (green), and hybridized rRNA (red). Location of methylation is denoted as $5^{\prime}$ bps from Box D/D'. (C) Assemblage of protein factors on the snoRNA illustrates that SNU13 binds the K-turns which positions FBL at the site of methylation.

In addition to Box C/D snoRNAs, K-turns are found in multiple RNA species, including mRNAs, riboswitches, and small nuclear (sn)RNAs but were first discovered and described in ribosomal RNAs [10]. A canonical K-turn is composed of two stems separated by an internal loop. The first stem, termed the "canonical stem" (C-stem) or Stem-I, ends at the internal loop with two Watson-Crick base pairs, typically G-Cs. The second helical stem, termed the "non-canonical stem" (NC-stem) or Stem-II, begins with two non-Watson-Crick base pairs, typically sheared G-A base pairs. These are maintained by long-range interactions. Loss of this base-pairing prevents localization of Box C/D snoRNAs to the nucleolus [11]. Within the loop is an unpaired $U$ that induces a kink in the phosphodiester backbone that bends the helical axis by $\sim 120^{\circ}$. The $\mathrm{C}^{\prime}$ and $\mathrm{D}^{\prime}$ boxes have a reduced ability to form a K-turn because of the sequence degeneration.

Box C/D snoRNAs associate with four evolutionarily conserved proteins: Fibrillarin (FBL)/Nop1p, SNU13(15.5K)/Snu13p, NOP58/Nop58p, NOP56/Nop56p (Figure 1C). The catalytic methyltransferase 
is FBL [12]. Although originally identified in the slime mold Physarum [13], much of the early work on FBL relied on autoantibodies from patients with scleroderma [14]. Immunoprecipitations using these antibodies identified FBL as part of an RNP that contained snoRNAs that were later characterized as Box C/D snoRNAs. Human FBL is highly similar to its yeast homolog, NOP1, and human FBL can partially rescue viability in NOP1 mutant strains [15]. Interaction with the snoRNA depends upon SNU13, formerly $15.5 \mathrm{~K}$, which recognized the K-turn formed by the interaction between the C and D boxes [16]. Crystallographic data of SNU13 in complex with the U4 snRNA show that it interacts almost exclusively with the purine-rich internal loop where the bulged $U$ fits into a pocket and is stabilized by the tandem sheared G-A base-pairs $[17,18]$. Binding of SNU13 to this motif is essential for recruitment of other Box C/D snoRNP factors. In contrast, the sequence of stem-II of the K-turn is essential for interaction of NOP56, NOP58, and FBL, but not SNU13 [11].

The assembled snoRNP mediates site-specific 2'-O-methylation through antisense guide base-pairing. Early work showed that specific snoRNA species could hybridize with mature rRNA species through canonical Watson-Crick base-pairing [19], which was later extended to other snoRNA species [20-23]. This work, coupled with the observation that the hybridization occurred at sites of methylation, suggested that these interactions served as guide RNAs. Proof came shortly after that Box C/D snoRNA hybridization to rRNA directed sites of methylation $[5,24,25]$. This allows for a common set of proteinaceous components to be assembled on specific guide RNAs in a modular manner. This mode of regulation has become a repeated feature of evolution as it was discovered that microRNAs and CRISPR RNAs use this same strategy to determine their RNA targets. Base-pairing occurs immediately $5^{\prime}$ of the $\mathrm{D}$ and $\mathrm{D}^{\prime}$ boxes. This positions the rRNA to be methylated at the active site of FBL located 5 nucleotides from the $5^{\prime}$ end of Box D [5,26,27].

Take home message: Box C/D snoRNPs catalyze the deposition of $2^{\prime}-O$ methylation using RNA-RNA base-pairing to direct target sites. FBL is the catalytic component of the Box C/D snoRNP.

\subsection{Box H/ACA snoRNAs}

Box H/ACA snoRNPs catalyze the isomerization of uridine to pseudouridine [28,29]. To generate $\Psi$, uridine is rotated $180^{\circ}$ around the $\mathrm{C}_{6}-\mathrm{N}_{3}$ axis to generate a carbon-carbon glycosidic bond as compared to the carbon-nitrogen glycosidic bond in uridine (Figure 2A). This rotation allows for $\Psi$ to make more hydrogen bonds by freeing up $\mathrm{N}_{1}$.

That Box H/ACA snoRNAs constitute a separate class of snoRNAs was recognized after the characterization of Box C/D snoRNAs. Originally characterized by the lack of the conserved C and D boxes, it was later observed that these snoRNAs contained a conserved ACA sequence at their $3^{\prime}$ ends [30]. Later, it was shown that these have two stem-loop structures separated by a conserved single-stranded motif that was termed the "hinge" region, or $\mathrm{H}$ box, with a consensus sequence of ANANNA [31] (Figure 2B). Secondary structure analysis also predicted internal loops within each stem-loop. These internal loops end up serving as the guide sequences similar to those $5^{\prime}$ of Box D in Box C/D snoRNAs. The uridine residue to be modified is positioned at the base of the stem-loop in a site known as the "pseudouridylation pocket". Efficient pseudouridylation requires three structural motifs [32]: (1) Two stable hairpins containing pseudouridylation pockets, 2) approximately 15 nucleotides between the target pseudouridine and either Box H or ACA, and (3) a sufficient amount of base-pairing between the target RNA and the snoRNA. However, what constitutes a sufficient amount of base-pairing is still under investigation. The base-pairing constraints between rRNA and Box H/ACA seem to be less rigid than for Box C/D snoRNAs that adhere to a +5 base-pair rule. At a minimum, eight base-paired nucleotides are required for pseudouridylation but the flexibility of the pseudouridylation pocket allows for multiple unpaired nucleotides [33]. The higher the degree of canonical base-pairing correlates with the increased rate of pseudouridylation [34]. However, affinity does not correlate with pseudouridylation as multiple near-cognate interactions can have high affinity but reduced pseudouridylation activity. 
A

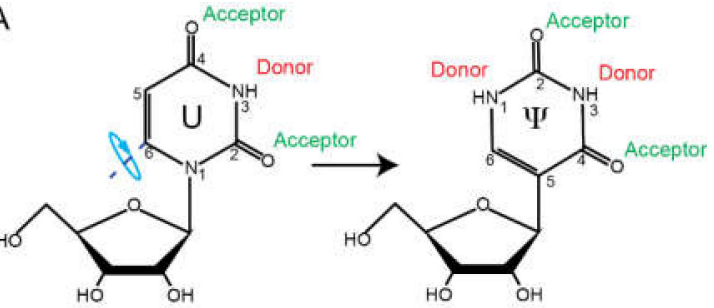

C

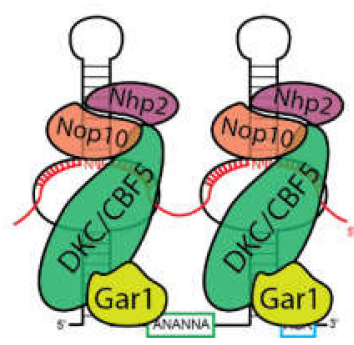

B

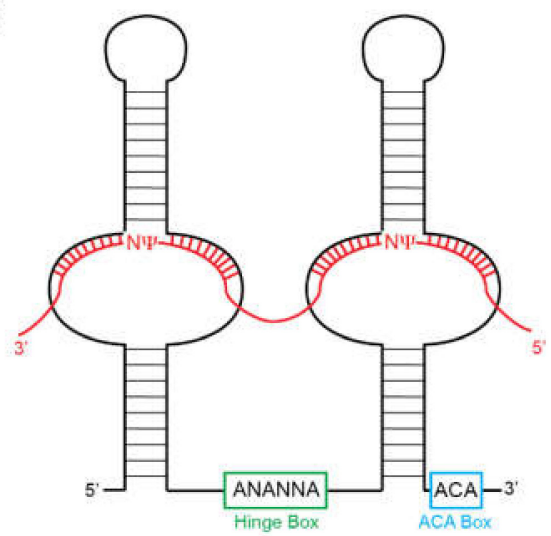

Figure 2. Box H/ACA snoRNPs. (A) Isomerization uridine to pseudouridine is catalyzed by Box $\mathrm{H} / \mathrm{ACA}$ snoRNAs. This generates additional hydrogen bonding capacity that aids in maintaining the ribosome structure. (B) Secondary structure of the Box H/ACA snoRNAs, indicating the location of the hinge $(\mathrm{H})$ box (green), ACA box (blue), and hybridized rRNA (red). Pseudouridylation occurs in the "pseudouridylation pocket" at the base of the hairpins. (C) Assemblage of protein factors on the snoRNA.

Pseudouridylation requires the assembly of a H/ACA snoRNP composed of the snoRNA and four protein co-factors: NHP2, NOP10, Gar1, and Dyskerin (DKC1)/Cbf5 (Figure 2C). The first of these to be identified in yeast was Gar1, which was shown to be required for pre-rRNA processing and to associate with a subset of snoRNAs, which were later shown to be H/ACA snoRNA [35]. Later work showed that it was required for pseudouridylation [36]. Bioinformatic searches for proteins related to bacterial pseudouridine synthetases (PUS) identified DKC1/Cbf5 as the possible catalytic component of the Box H/ACA snoRNP, which was confirmed experimentally [37,38]. Chromatographic separations and affinity purifications identified Nhp2 and Nop10 as the final components of the Box H/ACA snoRNP [38,39]. Nhp2 is not required for guide RNA binding, but is absolutely critical for efficient pseudouridylation [40].

Take home message: Box H/ACA snoRNPs catalyze the conversion of uridine to pseudouridine using RNA-RNA base-pairing to direct target sites. DCK1/Cbf1 is the catalytic component of the H/ACA snoRNP.

\section{Transcription and Processing of snoRNAs}

SnoRNAs are found in different genomic contexts that broadly fall into two sub-dividable categories: Independent transcription units and intronically encoded snoRNAs (Figure 3). In yeast and plants, most snoRNAs are found as independently transcribed genes, either as monocistronic or polycistronic units. The former is more common in yeast, while the latter is more common in plants. Some metazoan snoRNA genes exist as independent genes, but these are among the most essential (e.g., U3, U8, and RMRP). The majority of the information regarding the promoters of independent snoRNAs genes comes from yeast, but this data is still lacking. Many yeast snoRNA genes drive transcription from TATA-containing promoters downstream of an A/T rich region and a Rap1 binding site [41]. Rap1 is a transcription factor that is also necessary for transcription of ribosomal protein genes in yeast, which may serve to integrate these processes in ribosome biogenesis [42]. Subsequently, Tbf1 was identified as a second transcription factor necessary for snoRNA transcription [43]. In humans, the structure of independently transcribed snoRNA promoters is largely unknown although some progress has been made through bioinformatic analysis [44]. 


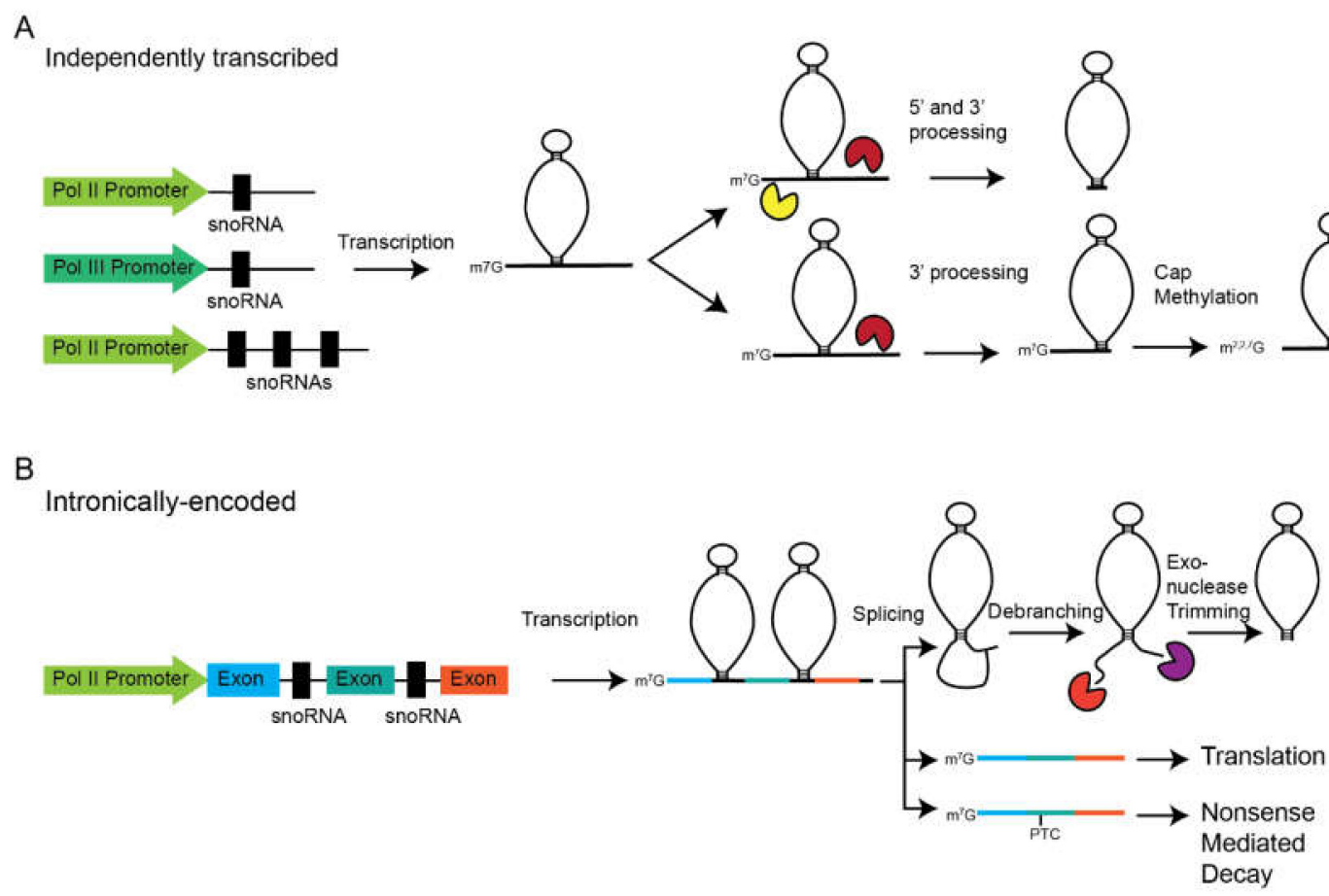

Figure 3. SnoRNA processing pathways. SnoRNAs are either independently transcribed or intronically encoded. (A) Independently transcribed snoRNAs exist as mono- or polycistronic units that are transcribed by RNA polymerase II or III. A trimethylguanosine $\left(\mathrm{m}^{2,2,7} \mathrm{G}\right)$ cap can be added or the $5^{\prime}$ end can be cleaved off. The $3^{\prime}$ end processing is required for final maturation of both capped and uncapped snoRNAs. (B) Intronically encoded snoRNAs are transcribed by RNA polymerase II from the promoters of their host genes. The host gene can encode a functional protein or a noncoding transcript that is often degraded by nonsense-mediated decay due to the presence of a premature termination codon (PTC). Maturation of the snoRNA requires mRNA splicing and debranching of the snoRNA-containing intron followed by exonucleolytic trimming. We presented Box C/D snoRNAs, but Box H/ACA snoRNAs undergo the same maturation pathway.

While RNA polymerase II (Pol II) transcribes the majority of independently transcribed snoRNA genes, there are some important exceptions. In yeast, all snoRNAs are transcribed by RNA Pol II except snR52, which is transcribed by RNA Pol III [45-47]. In metazoans, more independently transcribed snoRNA genes are transcribed by RNA polymerase III. In Caenorhabditis elegans, as many as 59 snoRNA genes are transcribed by RNA polymerase III [48] and at least two in Drosophila [49]. Of particular note are some homologous snoRNA genes that have switched polymerases throughout evolution. The U3 snoRNA, a critical snoRNA necessary for rRNA maturation (see below), is transcribed by RNA polymerase II in yeast and in humans [50-52]. Yet, in plants, the U3 snoRNA is transcribed by RNA polymerase III [53]. In humans, RMRP, a non-canonical snoRNA is transcribed by RNA polymerase III [54], but in yeast its homolog, NME1, is transcribed by RNA polymerase II [55].

Following transcription, pre-snoRNAs must be processed to generate a mature snoRNA (Figure 3A). This was recently covered in an excellent review [56], so we will only cover the basics here. Since most yeast snoRNAs are transcribed as independent transcription units, the majority of the data regarding the maturation of this class of snoRNAs comes from yeast. Transcription termination and $3^{\prime}$ end formation is facilitated by the Nrd1-Nab3-Sen1 (NNS) complex and Pcf11 [57,58]. Following cleavage, the $3^{\prime}$ end is exonucleolytically trimmed by the exosome to generate the mature $3^{\prime}$ ends [59]. Initially, the $5^{\prime}$ end is capped with a canonical $\mathrm{m}^{7} \mathrm{G}$ cap. However, this is either removed by Rnt1 [60], a member of the RNase III family, or converted to a $\mathrm{m}^{2,2,7} \mathrm{G}$ trimethylguanosine cap by TGS1 [59]. If the cap 
is removed, the $5^{\prime}$ end is trimmed by the exonuclease Rat1 and Xrn1 [61]. Cleavage by Rnt1 occurs co-transcriptionally and facilitates efficient $3^{\prime}$ end processing [62].

Higher eukaryotes have largely embraced a more nuanced mechanism of snoRNA transcription (Figure 3B). Rather than being transcribed as individual genes, metazoan snoRNA genes are largely found within the introns of host genes. The presence of the three copies of the U14 (SNORD14) snoRNA localized to the introns of the hsc70 gene was discovered in humans, mice, and rats [63]. Later, it was shown that this was processed from these snoRNAs and could be processed from the introns of pre-mRNA in a Xenopus injection system [64]. Later work showed that this was not a unique situation as the U15 (SNORD15) snoRNA was identified to be localized within an intron of the RPS3 gene and processed from its pre-mRNA [65]. The discovery of a ribosomal protein gene hosting a snoRNA portended the discovery that many intronically encoded snoRNAs are found within genes encoding ribosomal biogenesis or translational machinery. For example, more than a third of ribosomal protein genes host at least one snoRNA. Some ribosomal protein genes host multiple snoRNAs, such as RPL7A or RPL13A, which hosts four snoRNAs each. Theoretically, this arrangement allows for coupled synthesis of ribosomal proteins and snoRNAs which are required for modification of rRNA. An interesting case of coregulation has been shown for NOP56 and snoRD86 [66]. NOP56 is a component of the Box C/D snoRNP complex that has been proposed to function in "locking in" the final conformation of snoRNPs [67]. When NOP56 protein levels are high, free NOP56 binds to the SNORD86 in the intron of the NOP56 pre-mRNA and alter splicing to generate a NOP56 mRNA with a premature termination codon. Thus, this isoform of NOP56 is degraded via nonsense-mediated decay (NMD). Alternatively, when NOP56 levels are limiting, SNORD86 is unbound and NOP56 pre-mRNA is spliced to generate an mRNA that encodes a full-length protein.

Another important set of host genes are those that appear to have no coding potential and also do not appear to function as long noncoding (lnc)RNAs. Among the most noteworthy is the U22 host gene (UHG), which, in addition to U22 (SNORD22), hosts seven additional snoRNAs (U25-U31) [68]. All snoRNAs in UHG are Box C/D snoRNAs. After splicing, the UHG mRNA transiently associates with ribosomes but is then rapidly degraded by nonsense-mediated decay (NMD), suggesting that it has no purpose other than to serve as a host to these eight snoRNAs. A second member of this class was discovered soon after called gas5, which hosts 10 snoRNAs (nine in mouse) of the Box C/D family [69]. Similar to UHG, GAS5 mRNA is rapidly degraded in normal growing cells. However, GAS5 mRNA is stabilized in multiple different cancer types and appears to have functions distinct from its snoRNA encoding activity [70]. Subsequently, other host genes, such as U17HG [71], U19HG [72], and U50HG [73], have been identified. Strikingly, all of these host mRNAs contain $5^{\prime}$ terminal oligopyrimidine (5'TOP) motifs. These motifs are thought to regulate translation through an mTOR-dependent mechanism [74]. What is worthwhile to note here is that all ribosomal proteins are encoded by mRNAs that contain 5'TOP motifs, potentially providing a link between different classes of snoRNA host genes.

Again the molecular intricacies of snoRNA excision from introns has been covered in depth recently [56], so we will only cover basics here. The basics of processing are similar to that of independently transcribed snoRNA genes: After $5^{\prime}$ and $3^{\prime}$ processing, final maturation takes place by exonucleolytic trimming. However, this can occur via two pathways: A splicing-dependent and splicing-independent pathway [75]. The splicing-dependent pathway appears to be the major pathway. Here, the splicing machinery removes the intron leaving a lariat containing the pre-snoRNA. In this pathway, maturation depends upon linearization by the debranching enzyme [76]. At this point, $5^{\prime}$ to $3^{\prime}$ and $3^{\prime}$ to $5^{\prime}$ exonucleases trim to generate the mature $5^{\prime}$ and $3^{\prime}$ ends [77]. The second, minor pathway does not rely on intron excision followed by debranching. Instead, a stem structure is formed at the base of the pre-snoRNA that is cleaved, releasing the snoRNA from the larger precursor [75]. Unlike independently transcribed snoRNA genes, intronically encoded genes lack a $5^{\prime}$ cap, instead of containing a $5^{\prime}$ monophosphate generated after exonucleolytic trimming. 
Assembly of both Box C/D and Box H/ACA snoRNPs require multiple assembly factors that mediate RNP formation and trafficking from the site of transcription, through Cajal bodies and to the nucleolus. This complex process has recently been reviewed in [78]. However, one complex of note is the HSP90/R2TP chaperone system. Originally discovered in yeast via proteomic analysis, the R2TP complex is composed of Rvb1, Rvb2, Tah1, and Pih1 and interacts with HSP90 [79]. The identification of the human complex, containing homologs RUVBL1, RUVBL2, RPAP3 and PIH1D1, demonstrating that this is a conserved complex [80]. Despite having unrelated RNA structures and proteinaceous components, this complex aids in the assembly of both Box C/D and Box H/ACA snoRNPs [81]. Depletion of RUVBL2 leads to a loss of Box C/D and Box H/ACA snoRNAs and to a defect in the trafficking of snoRNP proteins to the nucleolus [82].

Take home message: Genomically, snoRNAs are found as independent transcription units or hosted within introns of mRNAs. Both require post-transcriptional processing and assembly with proteinaceous components.

\section{Role of Modifications in Ribosome Function}

In many cases, the roles of rRNA modifications remain enigmatic. The conservation and clustering of modification at functional centers, such as the peptidyl transferase center or the subunit interface, point to their importance. With regards to ribosome structure and stability, $2^{\prime}-O$-methylation increases hydrophobicity and pseudouridylation allows for additional hydrogen bonding. Both of these properties can stabilize interactions or provide rigidity. In yeast, global loss of either $2^{\prime} \mathrm{Ome}$ or $\Psi$ generated through the expression of catalytically dead mutants of Nop1 (FBL) and Cbf5p (DKC1) results in severe phenotypes $[12,83]$. Inactivating mutations to DKC1 in mammals (D95A) expectedly prevents pseudouridylation and reduces translation rates and fidelity [84]. However, preventing individual modifications through abrogation of a single snoRNA rarely has dramatic effects [85]. However, there are some of note. In yeast, snR10 catalyzes the conversion of $U_{2923}$ to $\Psi_{2923}$ in the $25 \mathrm{~S}$ rRNA. Deletion of this snoRNA renders cells more susceptible to osmotic and cold stresses [86]. However, slightly complicating this data is that loss of this snoRNA also reduces the efficiency of pre-rRNA processing (discussed below) [87]. Yet, there is an observed decrease in translation efficiency that is more likely tied to modification rather than processing [88]. Again, in yeast, loss of methylation of $\mathrm{U}_{2918}$ in the $25 \mathrm{~S}$ rRNA reduced growth and exhibited translational defects [89]. The importance of this methylation is revealed by the fact that it is deposited by two redundant mechanisms, snR52- and spb1-mediated methylation. Additionally, methylation of the equivalent site in Escherichia. coli is required for optimal fitness [90]. However, the importance of these individual modifications appears to be the exception, rather than the rule. Yet, the fact that snoRNAs, components of the snoRNPs, and sites of modification are under selective pressure validates their importance. Further work demonstrated that rather than acting individually, many of these modifications have a cumulative and synergistic effect on ribosome function. Loss of six $\Psi$ in the peptidyl transferase center of the large subunit greatly reduces translation rates and polysome assembly [88]. An interface between the large and small subunits occurs between Helix 69 of the large subunit and helix 44 of the small subunit [91]. Helix 69 contains

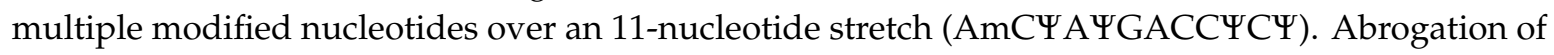
these modifications through disruption of snoRNAs impairs cell growth, disrupts ribosome structure, and alters translational efficiency [92]. A cluster of snoRNP-deposited modifications in the decoding center of the large subunit is also required for efficient translation [93].

Take home message: Multiple chemical modifications of rRNA have a cumulative effect on ribosome activity.

\section{Pre-rRNA Processing}

While most snoRNPs function in rRNA modifications, a subset directs rRNA processing. While loss of a single snoRNA that guides modification is rarely detrimental, the loss of a snoRNA that directs processing is often lethal. The rRNA maturation is a baroque process, requiring multiple endonucleolytic 
cleavage and exonucleolytic trimming reactions (Figure 4). Ribosomes contain four mature rRNAs, yet they are generated from two precursor molecules. The pre-5S rRNA is transcribed by RNA polymerase III and requires exonucleolytic trimming to generate the $5^{\prime}$ and $3^{\prime}$ ends. The remaining rRNAs are generated from long polycistronic precursors called the 35S rRNA in yeast or 47S rRNA in mammals. These contain the 18S, 5.8S, and 25/28S rRNA separated by two internal transcribed spacers (ITS1 and ITS2) and flanked by two external transcribed spacers (5'ETS and $3^{\prime}$ ETS). Within these spacers are multiple sites that are targeted by nucleases that mature the initial precursor into mature rRNAs. The majority of these processing events occurs in the nucleolus, although final maturation occurs in the cytoplasm.

A

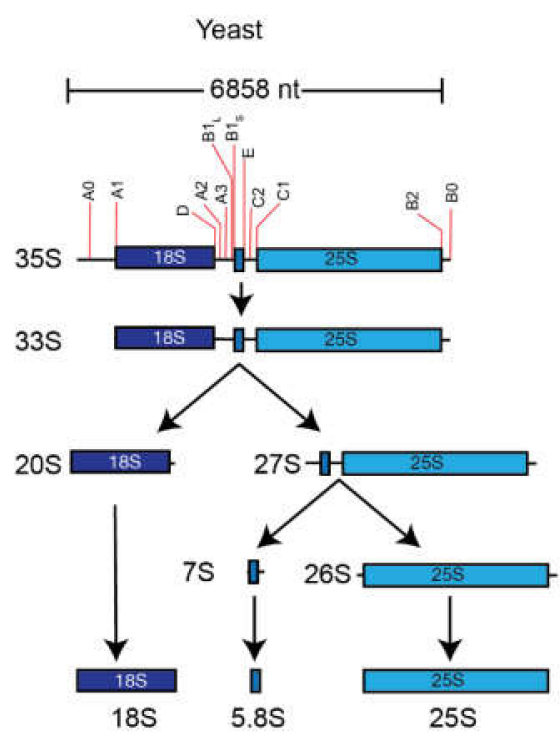

B

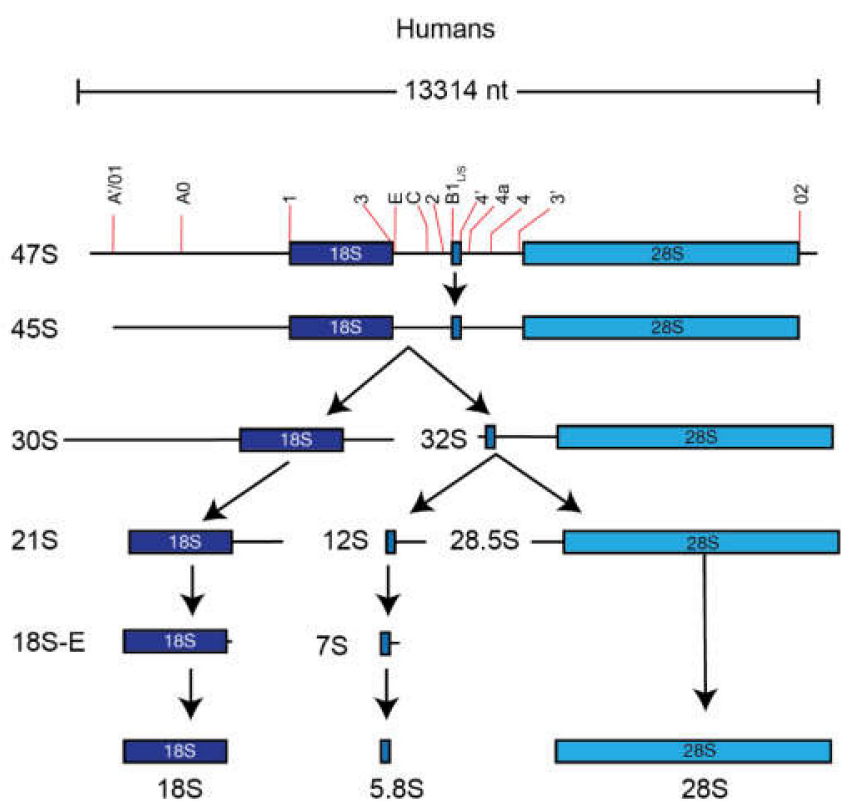

Figure 4. Simplified pathway of rRNA processing. (A) Yeast and (B) human rRNAs are generated from long polycistronic precursor molecules that must be processed to generate the mature rRNAs. This represents a simplified rRNA processing pathway in each organism, based on [94]. Note that there are minor pathways that are omitted from this schematic.

\section{The snoRNPs' Role in rRNA Processing}

\subsection{U3 (SNORD3) SnoRNP}

The U3 snoRNP is a member of the Box C/D family that typically facilitates $2^{\prime}$-O-methylation of ribose sugars (Figure 5A). However, U3 has not been shown to guide any chemical modifications. Instead, the U3 snoRNP is essential for the formation of the small subunit (SSU) processome, a multi-subunit complex that directs maturation of the $18 \mathrm{~S}$ rRNA and $40 \mathrm{~S}$ small subunit. 
A

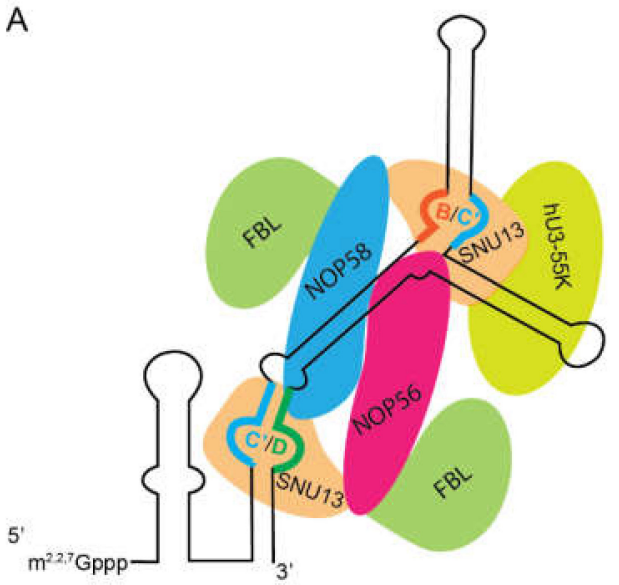

B

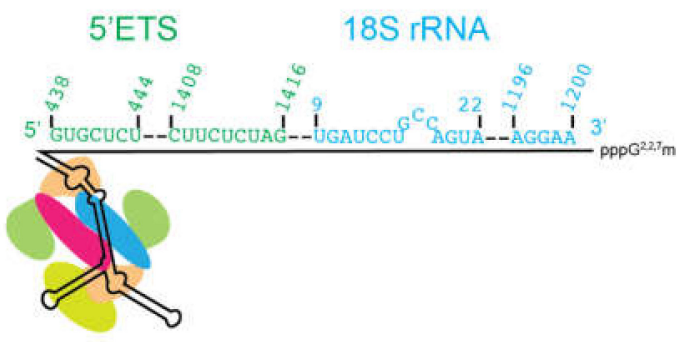

Figure 5. U3 snoRNP. (A) Secondary structure of the U3 snoRNA with protein components. Note that SNU13 still binds k-turns, here formed by Box $C^{\prime}$ (blue) and Box D (green) and Box $C^{\prime}$ (blue) and Box B (Red). The altered structure of the U3 snoRNA results in FBL not being positioned for 2'-O- methylation. (B) The $5^{\prime}$ extension forms multiple base-pairs with the pre-rRNA. Two different stretches in the $5^{\prime}$ ETS (green) and the 18S rRNA (blue) are bound. Dashed lines indicate looped-out stretches of rRNA. Numbers indicate position in the 47S rRNA (green) or 18S rRNA (blue). Note that this schematic does not fully represent looping out. Secondary structure modified from predictions on snoRNABase [95].

The U3 snoRNA was first identified by fractionation of RNA from the rat liver [96]. Further fractionation of the uridine-rich 7S fraction identified RNA species that were termed U1, U2, and U3 [97]. This RNA was soon shown to associate with ribosomes, giving the first hints at its possible function in cells $[98,99]$. Like other independently transcribed snoRNAs, the U3 contains a trimethylguanosine $\left(\mathrm{m}^{2,2,7} \mathrm{G}\right)$ cap [100]. Cloning of the human and rat U3 snoRNA genes significantly increased progress on understanding the role of this abundant RNA [101,102].

The fact that the U3 snoRNA will interact with rRNA in deproteinized cell extracts suggested that it interacted with these RNAs through base-pairing [98]. Using psoralen-assisted UV crosslinking, the U3 snoRNA was shown to crosslink to RNA contained within the nucleolus in cell [103]. These techniques were refined and it was later shown that the U3 snoRNA crosslinked in the $5^{\prime}$ external transcribed spacer, immediately downstream of the primary rRNA processing site, termed $\mathrm{A}^{\prime} / 01$, in mammalian cells [104]. Later, U3 snoRNA base-pairing to the 5'ETS was shown to be conserved in yeast [105]. The $5^{\prime}$ end of the U3 snoRNA can fold into a hairpin in isolation (Figure 5A), but the $5^{\prime}$ end of the snoRNA serves as the main platform for base-pairing with the pre-rRNA and thus this hairpin must unfold (Figure 5B). The length of this $5^{\prime}$ extended regions interacts with various points of the $5^{\prime}$ ETS and $18 \mathrm{~S}$ rRNA in which the intervening sequences are looped out, helping guide the formation of the ribosome [106].

Several studies proposed that U3 was involved in rRNA processing [107-110]; however, conclusive proof that U3 is necessary for processing came from the labs of Joan Steitz and Barbara Sollner-Webb in 1990 [111]. Micrococcal nuclease treatment of nuclear extracts inhibited the processing of an rRNA substrate in vitro, while DNase I treatment had no effect, thereby establishing the necessity for an RNA co-factor. Through several rounds of immunodepletion using antisera from scleroderma patients against FBL, a component of the U3 snoRNP, they were able to deplete nuclear processing extracts of U3 snoRNA. Upon depletion, these extracts failed to process rRNA. Finally, to demonstrate that U3 was involved and not another FBL-bound snoRNA, the authors demonstrated that oligonucleotide-directed, RNase H-mediated cleavage of U3 similarly blocked rRNA processing. Shortly afterwards, the necessity for U3 in rRNA processing was shown in living cells after the injection of U3 blocking oligos into frog oocytes [112]. Later, the necessity of U3 snoRNA in rRNA processing was shown in yeast by depleting the U3 snoRNA through use of a galactose inducible promoter [113]. 
While the snoRNA itself and base-pairing of the snoRNA to the 5'ETS of the rRNA precursor is required for activity, it is not sufficient for cleavage. Assembly of the snoRNA into a snoRNP is necessary for activity. Autoantibodies against FBL coprecipitated the U3 snoRNA. In yeast, depletion of FBL was shown to have the same effect on rRNA processing as depletion of the U3 snoRNA, suggesting that the interaction between the two is required for activity [114]. The U3 snoRNP contains all canonical members of Box C/D snoRNPs (i.e., SNU13 (15.5K), NOP56, and NOP58) [110]. However, the uniqueness of the U3 snoRNP is highlighted by its additional protein components. One of the most prominent additional factors is called hU3-55K in humans or Rrp9 in yeast. This protein was first identified in Chinese hamster ovary cells through affinity chromatography [115]. Similar to other components of the U3 snoRNP, U3-55K is required for viability and rRNA processing [116]. More recently, Clerget and colleagues showed that yeast pre-rRNA processing defect was significantly enhanced when specific regions of the Rrp9 and U3 snoRNA were mutated [117]. The locations that each protein binds to the U3 snoRNA were identified using a technique known as crosslinking and analysis of cDNA (CRAC) [118]. Two other components were identified, known as Sof1 and Mpp10 [15,119].

The identification of Mpp10 proved particularly fruitful in the next major discovery regarding the U3 snoRNP. The U3 snoRNP is a central component of a large processing complex called the small subunit (SSU) processome [120]. Using tandem affinity purification of Nop5/58, the yeast homolog of NOP58, to first purify all Box C/D snoRNAs followed by Mpp10 to purify U3 snoRNP complexes, Dragon et al. showed that the U3 snoRNP associated with at least 28 in a complex of approximately 2.2 MDa. They termed the previously unknown proteins "U-three proteins" or UTPs. Depletion of any of these proteins blocked the formation of the $18 \mathrm{~S}$ rRNA. Finally, this led to the identification of the "terminal knobs" first seen by Oscar Miller in chromatin spreads of rDNA repeats in 1969 [121]. The Baserga lab determined that these terminal knobs were the SSU processome through depletion of these newly identified UTP proteins. It is worth noting that these terminal knobs had previously been suggested to contain rRNA processing complexes [122]. This discovery along with major advances in cryoelectron microscopy led to the first structures of the SSU processome, alternatively called the $90 \mathrm{~S}$ pre-ribosome $[106,123,124]$. More recently, the high-resolution structure of the SSU has been solved in yeast [125] and in the thermophilic fungus Chaetomium thermophilum [126].

Take home messages: The U3 snoRNP is required for small subunit assembly.

\subsection{RNA Component of RNase MRP Complex (RMRP)}

RMRP is a non-canonical snoRNA that belongs to neither the Box C/D nor Box H/ACA classes. That RMRP has a role in human pre-rRNA processing has long been established, but the precise role was not understood until recently. Only with the generation of CRISPR/Cas9-mediated deletions of the RMRP gene was it definitively shown that it directs the cleavage at site 2 in ITS1 of human pre-rRNA [127]. RMRP is the RNA component of the RNase MRP (ribonuclease mitochondrial RNA processing) complex. The RNase MRP endonuclease was originally identified in mouse, showing its ability to cleave the mitochondrial RNA that functions as a primer for mitochondrial DNA replication [128]. RMRP contains a decamer sequence, 5'-CGACCCCUCC-3', complementary to a conserved sequence adjacent to the enzymatic cleavage site on the mitochondrial RNA substrate, and is present in the RNase MRP RNA [129-131]. Despite initially being presumed to be active in the mitochondria, RMRP is nuclear encoded. Human RMRP is 267 nucleotides long and shares $84 \%$ homology to the corresponding mouse gene; surprisingly, at least 700 nucleotides of the immediate $5^{\prime}$-flanking region are conserved [132]. The sequence of the RMRP transcript is highly conserved among a variety of different species, including human, mouse, rat, cow, Xenopus, yeast, Arabidopsis, and tobacco [133]. The length of the transcript varies among different species. Secondary structure models for RMRP reveal a complex structure, the core of which is required for the assembly and function of the ribonucleoprotein complex $[134,135]$. It has been shown that the MRP RNA of human cells is identical to the "Th" or 7-2 RNA originally described as being precipitable with autoimmune sera of 
scleroderma patients [136]. Since this species (MRP/Th) is known to be present in the nucleolus [137,138], it is most likely that RMRP could play an essential role in the metabolism of rRNA. More evidence that came from the immunolocalization data suggested that RMRP may be involved in stages of ribosome biogenesis in the nucleolus [139]. The apparent predominant localization of RMRP to the nucleolus suggests that RNase MRP might somehow be involved in nuclear rRNA processing.

In Saccharomyces cerevisiae, the RMRP ortholog NME1 (nuclear mitochondrial endonuclease 1) showed an essential role in cell viability, indicating a critical nuclear role for RNase MRP [55]. MRP cleaves the pre-rRNA at the $A_{3}$ cleavage site in yeast pre-rRNA, which is thought to be the functional equivalent of site 2 in humans [140]. Further, conditional depletion of RNA component of the enzyme showed that this is responsible for the maturation of $5.8 \mathrm{~S}$ rRNA. It was found that there was a reversal in the stoichiometry of the two mature forms of 5.8S rRNA; in the MRP RNA-depleted condition, the 7-nucleotide-longer version of 5.8S rRNA was 10 times more abundant than the shorter species lacking this 7-nucleotide sequence at the $5^{\prime}$ end. These results were in contrast to the normal stoichiometry in which the shorter version of $5.8 \mathrm{~S}$ rRNA is 10-fold more abundant than the slightly longer version. It is worth mentioning that a particular A to $G$ transition at position 122 at RNA sequence defines its functional capacity [141-143]. High-copy suppressor analysis of this point mutation leads to identification of interacting protein and it was shown that SNM1 protein is the first identified protein component unique to the RNase MRP enzyme complex. The protein contains a leucine zipper motif, a zinc-cluster motif, and a serine/lysine-rich tail [144]. Salinas et al. identified another protein component of this endonuclease and named it RMP1, for RNase MRP protein [145]. Characterization of the entire RNase MRP endoribonuclease is found to be complicated by the fact that eight of the known proteins of the complex are shared with a related ribonucleoprotein, called RNase P. RNase $\mathrm{P}$ is also an endoribonuclease but it is mainly involved in tRNA precursors' maturation [146].

Another role has been assigned to this RMRP by observing a delay in the progression of the cell cycle at the end of mitosis in some nme1 mutants [147]. This is caused by an increase in CLB2 (B-type cyclin) mRNA levels leading to increased Clb2p (B-cyclin) levels and a resulting late anaphase delay. One reason for the cell cycle delay in these mutants might be the increased level of CLB2 mRNA. Normally, the RNase MRP complex cleaves the 5' UTR of CLB2 mRNA. That, in turn, causes a rapid degradation of CLB2 mRNA and efficient cell cycle progression [148].

Take home message: RMRP is a non-canonical snoRNA that is involved in processing of ITS1.

\subsection{Other snoRNAs Necessary for rRNA Processing}

The U3 and RMRP are the two-best characterized snoRNPs that are necessary for rRNA maturation, but they are not unique. The U8 and U13 snoRNAs are also independently transcribed snoRNAs genes and are necessary for rRNA processing [68]. Both of these are members of the Box C/D family of snoRNPs. U8 appears to be a vertebrate-specific snoRNA that is required for the maturation of the 5.8S and 28S rRNAs [149]. Disruption of U8 snoRNP function in Xenopus results in failure to mature large subunit rRNAs. U8 is also necessary for large subunit processing in mice and was recently shown to be necessary in humans as well $[150,151]$. The critical nature of this snoRNA in vertebrates raises the question as to how yeast survive without this snoRNA. It has been proposed that portions of yeast ITS2 can adopt two different secondary structures, termed the "ring model" and "hairpin" model, that can independently guide processing events in the absence of the U8 snoRNP [152]. Upregulation of U8 is commonly seen in breast cancers and has been proposed to be a potential cancer biomarker [151].

The U13 snoRNA was among the earliest discovered snoRNAs [9]. Early work demonstrated that U13 was required for pre-rRNA processing through Watson-Crick base-pairing to the $3^{\prime}$ end of the 18S rRNA [153]. Despite this, the precise role of this snoRNA in pre-rRNA processing has remained enigmatic, but recent data raise some intriguing possibilities. The Suzuki lab found that the biogenesis of the $18 \mathrm{~S}$ rRNA was dependent upon $N^{4}$-acetylation of $\mathrm{C}_{1773}\left(\mathrm{ac}^{4} \mathrm{C}_{1773}\right)$ in yeast. Ultimately, they showed that this was dependent upon yeast acetyltransferase KRE33/RRA1. The human homolog of this protein, NAT10, performs the same function at $\mathrm{C}_{1842}$ of the human $18 \mathrm{~S}$ rRNA [154]. Further work 
suggested that this is also responsible for acetylation of $\mathrm{C}_{1337}$ of the $18 \mathrm{~S}$ rRNA in humans and $\mathrm{C}_{1297}$ of the $18 \mathrm{~S}$ rRNA in yeast [155]. But the more surprising result from Sharma et al. (2015) was that the U13 snoRNP was essential for deposition of this acetylation. In yeast it was shown that snR45 was the functional homolog of vertebrate $\mathrm{U} 13$ which guides acetylation of $\mathrm{C}_{1773}$, whereas snR4 directs acetylation of $\mathrm{C}_{1280}$. As $\mathrm{U} 13$ has not been shown to direct any 2'-O-methylations, it is intriguing to believe that this snoRNA has evolved to direct acetylation that is required for processing.

U14 has undergone intense study over the last 30 years and is also necessary for pre-rRNA processing although this may be linked to its ability to direct 2'-O-methylation. Like U3, U8, and U13, the U14 snoRNA is a member of the box C/D family, but unlike those, this snoRNA is intronically encoded, rather than being independently transcribed [63]. In yeast, depletion of the U14 results in misprocessing of the 18S rRNA [156]. Like other snoRNAs, U14 base-pairs with pre-rRNA which, in this case, is essential for maturation of the 18S rRNA [19,157]. This is also true in yeast [156]. However, yeast U14 is distinguished from its vertebrate homologs by the presence of a stem-loop domain that is essential for its function in pre-rRNA processing. This element, known as the Y-domain, for "yeast specific", is located between the regions that base-pair with rRNA [158,159]. Unlike U3, U8, or U13, the U14 snoRNP also functions in its canonical role as a Box C/D snoRNP by directing methylation of the 18S rRNA [160]. It is unclear if U14-dependent 2'-O-methylation is required for processing or if this is a separate function of the snoRNP.

In addition, several other snoRNPs have been shown to be necessary for efficient pre-rRNA processing; however, the precise mechanism by which they perform these functions is unknown. These include the U22 (SNORD22) [161], U17 (SNORA73)/snR30 [162,163], SNORA62 (E3), SNORA63 (E3) [164], and snR10 [87].

Take home message: Various snoRNAs have been implicated in processing of rRNA, but the precise mechanism by which they perform this function has yet to be described.

\section{Role of snoRNP-Mediated Modifications in rRNA Processing}

It is clear that snoRNAs are necessary for rRNA processing, particularly those discussed above (e.g., U3, RMRP). Indeed, even those that guide RNA modification have been shown to have a role in rRNA processing (e.g., snR10, U13, U14). However, showing that a particular snoRNA is required for processing does not distinguish between two possibilities: (1) That snoRNP:rRNA interaction is required for processing or (2) that chemical modification of particular nucleotides is necessary for processing. That is, it is possible that certain snoRNPs act as chaperones, changing the secondary structure of the pre-rRNA, which promotes efficient cleavage. Therefore, the snoRNP:rRNA interaction could serve to chemically modify the rRNA and alter the rRNA secondary structure.

Early work by the Darnell lab presented data demonstrating that 2'-O-methylation of ribosomal RNA was essential to pre-rRNA processing, but not for rRNA transcription [165]. Later work, using ethionine, a methionine analog that is not capable of acting as a methyl donor, confirmed these results [166]. Using cycloleucine, another inhibitor of methylation, others suggested that loss of 2'-O-methylation delayed or reduced the efficiency of processing, but did not completely abolish it [167]. Surprisingly, while 2'-O-methylation is evolutionarily conserved, the need for 2'-O-methylation in rRNA processing may not be. In E. coli, treatment with ethionine appears to have no effect on rRNA processing [168]. However, while rRNA maturation is unaffected, $50 S$ subunits from E. coli grown in ethionine were defective, but this appears to be due to lack of methylation of ribosomal proteins. The fact that rRNA methylation is not required for assembly of $E$. coli ribosomes may not be surprising since E. coli ribosomes can be assembled in vitro with submethylated rRNA [168]. Further, it is worth pointing out that 2'-O-methylation in E. coli is not meditated by snoRNAs. More surprising is that in yeast, some temperature-sensitive mutants in Nop1p/FBL that affect methylation do not impair rRNA biogenesis, but do prevent 2'-O-methylation [12]. Therefore, it seems as if higher eukaryotes are unique in the necessity of $2^{\prime}-O$-methylation for maturation of rRNA. 
It has been more difficult to determine the role of $\Psi$ in rRNA processing due to the lack of inhibitors of pseudouridylation, particularly in vertebrates; however, some progress has been made. In yeast, Cbf5p is essential for viability [169]. However, expression of catalytically dead (D95A) Cbf5p in $\Delta$ Cbf5p cells can rescue viability, but these cells lack $\Psi$ in rRNA [83]. Despite this, there was no apparent lack of effect on rRNA processing. Similar to yeast, DKC1 knockout causes embryonic lethality in mice [170], but MEFs, cells carrying catalytically dead (D125A) mutations, show defects in rRNA processing and synthesis [171]. These data are somewhat complicated by reduced levels of DKC1 in these cells. Regardless, the authors did find that mature rRNA from DKC1(D125A) cells were less stable, arguing that $\Psi$ has a role in stabilizing rRNA. In total, these data mirror that of $2^{\prime}-O-$-methylation in which $\Psi$ is required for processing in higher eukaryotes, but appears to be more dispensable in yeast. However, as mentioned above, while unmodified rRNA can be matured, the ribosomes they comprise are defective.

There are instances, such as the above-mentioned snR10, in which snoRNAs that direct modifications are necessary for processing [86,87]. Yet it has not been firmly established that modification is required or snoRNA:rRNA hybridization is required for processing. Also, pseudouridylation by snR35 converts $U_{1191}$ to $\Psi_{1191}$ which is further modified to 1-methyl-3- $\gamma$-( $\alpha$-amino- $\alpha$-carboxypropyl)-pseudouridine $\left(\mathrm{m}^{1} \mathrm{acp}{ }^{3} \Psi\right)$ [172]. This modification is required for normal processing of yeast $18 \mathrm{~S}$ rRNA. Failure to convert $U_{1191}$ to $\Psi_{1191}$ prevents deposition of $\mathrm{m}^{1} \mathrm{acp}^{3}$. As a result, the $20 \mathrm{~S}$ pre-rRNA never matures to the $18 \mathrm{~S}$ rRNA [93].

Take home message: There are specific instances in which chemical modification of rRNA aids in pre-rRNA processing, but most are dispensable. The trend is that these modifications are more required in higher eukaryotes than in yeast or bacteria.

\section{Diseases}

Loss of specific snoRNAs or reduction in the activity of catalytic components of snoRNPs have been tied to multiple disease states including congenital disorders and cancer. Here, we only focused on those involved in the regulation of ribosome biogenesis or activity, but it is worth mentioning that there are certain instances, such as deletion of SNORD116, which causes Prader-Willi syndrome, but appears unconnected to ribosome function. Recent work also shows that certain snoRNAs can direct modification of mRNAs and tRNAs that likely have a role in maintaining cellular homeostasis $[173,174]$.

Cartilage-hair hypoplasia $(\mathrm{CHH})$ is a form of dwarfism, first identified by Victor McKusik in Amish communities [175]. Patients with $\mathrm{CHH}$ are characterized by a short stature, hypoplastic hair, and short limbs. Mutations in the RMRP snoRNA were shown to be causative for CHH [176]. Subsequent work has revealed nearly 100 different mutations in the RMRP gene related to $\mathrm{CHH}$ (reviewed in [177]). Disease-associated mutations in RMRP disrupt normal rRNA processing [178], as does complete ablation of RMRP gene by CRISPR-Cas9 [127].

Another prominent disease related to snoRNP function is X-linked dyskeratosis congenita (X-DC). Classical X-DC is characterized by hematopoietic defects, such as bone marrow loss, and cutaneous abnormalities, such as abnormal pigmentation [179]. Mutations in DKC1 are prominent in X-DC, but non-X-linked mutations have also been found in other Box H/ACA components, NOP10 and NHP2 [180-182]. As components of the Box H/ACA snoRNPs, these factors are all necessary for pseudouridylation of rRNA; however, the precise molecular defect underlying X-DC has been controversial $[183,184]$. This is because these factors also associate with a non-canonical Box C/D snoRNA called telomerase RNA component (TERC), which is required for telomere maintenance [185]. Indeed X-DC patients have shorter telomeres which surely have a role in disease progression [186]. Yet, patients also see a defect in rRNA modification and translation. Mouse models of X-DC show a marked decrease in rRNA modifications [187]. These same models show defects in translation, particularly on those mRNAs that harbor internal ribosome entry sites (IRES) that facilitate cap-independent translation initiation [188]. These include alterations to the translation of the p53 mRNA, which may explain the increased susceptibility to cancer in X-DC patients [189]. X-DC-associated mutations in DKC1 reduce the basal level of particular snoRNAs, thereby reducing rRNA pseudouridylation [190]. These defects 
impair hematopoietic stem cell differentiation, likely leading to bone marrow failure. The linkage between hematopoietic defects in X-DC is part of a recurring theme in ribosome biology. Other defects in ribosome biogenesis, not necessarily related to snoRNPs, are termed "ribosomopothies" and often present in patients as anemias or other defects in hematopoiesis [reviewed in [191]]. These include Diamond-Blackfan anemia, Shwachman-Diamond syndrome, and Treacher-Collins syndrome. Recently, it was also shown that nucleophosmin (NPM), a prominent phosphoprotein in the nucleolus, is mutated in certain forms of dyskeratosis congenita [192]. Rather than causing defects in Box H/ACA snoRNPs and pseudouridylation, these mutations affect Box C/D snoRNPs and alter 2'-O-methylation of rRNA.

In recent years, it has also become clear that dysregulation of snoRNPs and rRNA modification is tied to oncogenesis. Much work on miRNA expression used snoRNAs as reference genes for qRT-PCR studies, until it was discovered that snoRNAs are misregulated in tumors [193]. The p53 is a direct regulator of FBL transcription and, therefore, a reduction or impairment of p53 results in increases in FBL levels [194]. Increased expression of FBL results in a concomitant increase of rRNA synthesis, but only slight changes to global rRNA methylation. Instead, there were dramatic changes to the pattern of methylation with some sites being increased five-fold and others being reduced by half. These changes to methylation altered the translational fidelity of ribosomes and increased the translation of mRNAs harboring IRES elements. These data parallel other data showing that decrease in pseudouridylation connected to X-DC reduced IRES-dependent translation [188]. The increase in FBL levels has been confirmed in mouse models of breast cancer that also show a marked increase in snoRNA levels [195]. In contrast to this data, it has been reported that acute leukemia is often tied to a global decrease in snoRNA levels [196]

While global increases in snoRNAs and FBL activity are tied to cancer development, there are also cases of specific snoRNAs being decreased in cancer. The snoRNA host gene GAS5 is significantly downregulated in breast cancer [197]. The U50 snoRNA is also hosted in a noncoding RNA that is mutated in B-cell lymphomas [73]. Subsequent work showed that U50 (SNORD50) was also misregulated in prostate and breast cancer $[198,199]$. Ectopic reintroduction of U50 is able to repress some of the cancer-associated phenotypes in breast cancer cells. U50 catalyzes the methylation of $\mathrm{C}_{2848}$ and possibly $\mathrm{G}_{2863}$ in the $28 \mathrm{~S}$ rRNA. However, it is also possible that U50 has a role in directly regulating the expression of KRAS [200]. One of the more recent surprising findings is that loss of a single snoRNA, SNORA24, synergizes with oncogenic RAS expression to promote cancer [201]. In this instance, SNORA24 guides conversion of $U_{609}$ and $U_{863}$ to $\Psi_{609}$ and $\Psi_{863}$, respectively. Particularly important here is $\Psi_{609}$, which is found in the decoding center of the ribosome. Loss of these modifications had little effect on global translation but were defective in tRNA selection and ribosome translocation. Further investigations have identified dozens of additional snoRNAs whose expression is significantly altered in tumors, either positively or negatively (reviewed in [202]). The mechanistic consequences of many of these misregulated snoRNAs are yet to be determined.

\section{Future Considerations}

Despite the fact that snoRNPs have been under intense study for 40 years, there is still much to be learned. Recent cryo-EM data have suggested the existence of several unknown rRNA modification [2]. There remain several "orphan snoRNA" that have not yet been shown to direct $\Psi$ or 2'Ome of rRNA or have a role in pre-rRNA processing. Given the recent discovery that some snoRNPs can direct acetylation of rRNA, a previously unknown role, it raises the possibility that snoRNPs may have a role in these yet-to-be-characterized modifications. However, it is worth pointing out that recent mass spectrometric analysis of rRNA were not able to confirm or identify these possible modifications [3]. These modifications would first need to be identified before proceeding with the investigation of what role snoRNPs have in this process.

Within the last decade, it was discovered that mature tRNAs serve as precursor molecules for smaller RNA species that have been designated by various names, such as tiRNAs, tRFs, and tRNA halves [203-206]. These fragments have various roles in biology, including regulating the epigenetic 
state of chromatin, global translation regulation, and miRNA-like mRNA silencing. At nearly the same time as tRNA-derived RNAs were discovered, it was also observed that snoRNAs are processed into smaller stable RNA species [207]. These RNA species were given the name snoRNA-derived RNAs (sdRNAs). Dozens of studies have confirmed the presence of these smaller RNA species. Yet, despite the progress made on characterizing the mechanisms through with tRNA-derived RNAs function, elucidating the molecular function of sdRNAs has lagged behind. Some data suggests that some sdRNAs may regulate mRNAs' splicing [208] and recent data point to the fact that they may have a role in regulating translation, similar to some tRNA-derived RNAs [209]. Whether this occurs through similar mechanisms to tRNA-derived fragments is unknown. However, YB-1, a protein that interacts with tRNA fragments to control their activity [210], also interacts with snoRNAs [211]. This protein has multiple cellular roles but is most actively involved in mRNA translation (reviewed in [212]). However, given the immaturity of the data surrounding these RNAs, it is equally possible that the sdRNAs regulate the activity of YB-1 as the converse.

An even less appreciated class of small RNAs are those derived from rRNAs, which were also discovered at the same time as tRNA-derived RNAs and sdRNAs [203]. Recent data confirms that they are abundant and that their biogenesis may be regulated [213]. However, little is known about their activity. Given that some snoRNPs direct cleavage of pre-rRNAs, it is possible that they also play a role in the biogenesis of these small RNAs. However, a more likely connection is through their ability to modify rRNA. The tRNAs are the only RNAs that are more heavily modified than rRNAs and differential modification of tRNAs has a clear role in directing the biogenesis of tRNA-derived RNAs (reviewed in [213]). By analogy, it is conceivable that modification of rRNAs by snoRNPs could similarly direct the biogenesis of rRNA-derived RNAs.

That differential modification of rRNAs may play a role in the generation of rRNA-derived RNAs leads to the most provocative current topic with regards to snoRNPs: Their potential role in the generation of "specialized ribosomes". While the possibility of such ribosomes has often been speculated, the discovery that mRNAs from Hox genes depends upon ribosomes with a precise set of associated proteins has accelerated research in this area [214]. As a basis for specialization, there must be clear evidence of heterogeneity in the ribosome pool. Work has progressed in this area by analyzing the protein complement of ribosomes. However, recently, it has become clear that rRNA modifications provide another, perhaps more prominent, layer of heterogeneity in ribosomes, that may lead to the identification of "specialized ribosomes". That snoRNPs are responsible for the deposition of these modifications makes them important players in this process. The development of new techniques have provided many insights into this possibility [215]. Initially, ribose methylation patterns in rRNAs were identified by labeling RNA with ${ }^{32} \mathrm{P}$-orthophosphate and ${ }^{14} \mathrm{C}$-methyl-methionine and conducting RNA fingerprinting [216,217]. Pseudouridylation patterns were mapped by RNA hydrolysis followed by thin layer chromatography [218]. More site-specific techniques were developed using CMCT modification followed by analysis of reverse transcription (RT) stops on sequencing gels [219,220]. CMCT will modify Us, $\Psi$ s, and Gs, but is easily removed from Gs and Us by mild alkaline treatment, leaving CMCT adducts only on $\Psi$. This bulky adduct blocks reverse transcriptase at sites of pseudouridylation. While these techniques were instrumental for establishing patterns of modification, they were not scalable. Since then, a large number of biochemical, chromatographic, and mass-spectrometric techniques have been developed. Over the past few years, new high-throughput and next-generation sequencing technologies in combination with biochemical approaches have drastically changed the field as they provide unprecedented information on the distribution, regulation, and functional dynamics of the RNA modifications [221-223]. These sequencing technologies in the mapping modified RNA or epitranscriptomics' marks and rely heavily on features such as, pre-enrichment capability (such as antibody enrichment), base-pairing interferences due to modified nucleotides, and bioinformatics tools [222,224-226].

Several high-throughput techniques have emerged to specifically analyze both $\Psi$ and 2'Ome. Multiple techniques aim at identifying 2'O-me in RNA and have been particularly useful in mapping this modification in rRNA [227]. These include RiboMeth-Seq [215], 2'O-Me-Seq [228], RiboOxi-Seq [229], 
and Nm-Seq [230]. RiboMeth-Seq has become one of the most widely utilized techniques and relies on the fact that 2'-O-methylated sites are more resistant to alkaline hydrolysis by several orders of magnitude when compared to unmethylated site. RNA is randomly hydrolyzed to short RNA fragments and small RNA sequencing libraries are prepared. Reads are aligned to rRNA and the location of $5^{\prime}$ and $3^{\prime}$ ends are determined. These ends reflect sites of hydrolysis and should be randomly distributed. Sites of methylation will be absent when mapped, revealing their location. CMCT modification has also been adapted for a high-throughput approach to map $\Psi$. Using the original approach, rather than analyzing single sites on sequencing gels, a linker is ligated to the $3^{\prime}$ end of fragmented RNAs, followed by reverse transcription. The $\Psi$ s can be mapped by analyzing RT stops after mapping to the genome [231-233].

Using these approaches, modification heterogeneity has been demonstrated by several groups and revealed with regards to 2'-O-methylation and pseudouridylation. Using RiboMethSeq in isogenic HCT116 cells that were either p53-positive or p53-negative, the Lafontaine and Motorin labs showed that loss of p53 affected the occupation of 2'-O-methylatiom at particular sites [234]. Sites of variability were largely found on the periphery of the ribosome rather than at functional centers. These data were mirrored by earlier work from the Nielsen lab that showed that rRNA from HeLa cells and HCT116 cells were differentially modified [235]. The changes in modification may reflect the changes seen in snoRNAs levels during the development of cancer. However, this was recently extended beyond the pathological setting when it was shown that there were developmentally regulated changes in rRNA methylation during mouse development [236]. In this instance, at least one differentially modified nucleotide occurs as a result of developmental regulation of the Gas5 gene that hosts several snoRNAs. The development of a quantitative mass spectroscopy-based approach to identify modified nucleotides called "stable isotope-labeled ribonucleic acid as an internal standard (SILNAS)" has revealed that, in addition to changes in 2'-O-methylation, there are specific sites of pseudouridylation that are differentially modified [3]. Alterations in snoRNA expression seen in disease states may be responsible for some of these changes seen in rRNA modification in cancer. Further work to determine the functional consequences of altered rRNA modification on ribosome activity in these contexts remains to be completed, but it raises many intriguing possibilities.

\section{Abbreviations/Nomenclature}

$\begin{array}{ll}\text { RNA } & \text { ribonucleic acid } \\ \text { bp } & \text { base pair } \\ \text { nt } & \text { nucleotide } \\ \text { rRNA } & \text { ribosomal RNA } \\ \text { mRNA } & \text { messenger RNA } \\ \text { snoRNP } & \text { small nucleolar ribonucleoprotein } \\ \text { snoRNA } & \text { small nucleolar RNA } \\ \text { snRNA } & \text { small nuclear RNA } \\ \text { G } & \text { guanosine } \\ \text { C } & \text { cytosine } \\ \text { A } & \text { adenosine } \\ \text { T } & \text { thymidine } \\ \text { U } & \text { uridine } \\ \text { I } & \text { pseudouridine } \\ 2^{\prime} \text { Ome } & 2^{\prime} \text {-O-methyl } \\ \text { RMRP } & \text { RNA component of mitochondrial RNA processing endonuclease } \\ \text { TERC } & \text { telomerase, RNA component } \\ \text { SNU13 } & \text { small nuclear ribonucleoprotein 13 } \\ \text { NOP58 } & \text { nucleolar protein 58 } \\ \text { NOP56 } & \text { nucleolar protein 56 } \\ \text { FBL } & \text { fibrillarin } \\ \text { CRISPR } & \text { clustered regularly interspaced short palindromic repeats } \\ \end{array}$




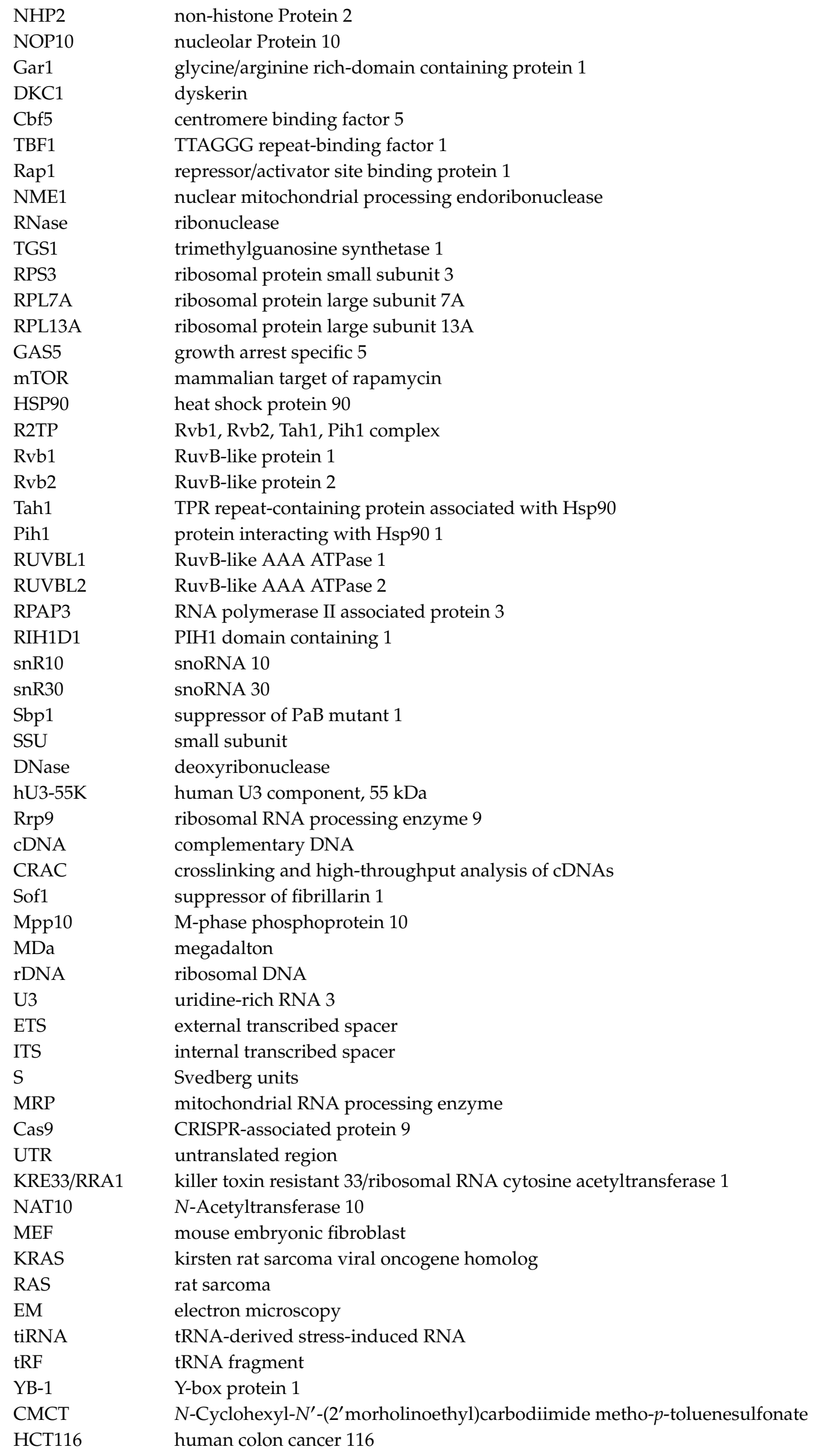


Funding: This work was funded by the National Institutes of Health, R00 GM124458 to SML.

Acknowledgments: We thank members of the Lyons lab for helpful discussion on this manuscript.

Conflicts of Interest: The authors declare no conflicts of interest

\section{References}

1. Boccaletto, P.; Machnicka, M.A.; Purta, E.; Piątkowski, P.; Baginski, B.; Wirecki, T.K.; De Crécy-Lagard, V.; Ross, R.; Limbach, P.A.; Kötter, A.; et al. MODOMICS: A database of RNA modification pathways. 2017 update. Nucleic Acids Res. 2018, 46, D303-D307. [CrossRef] [PubMed]

2. Natchiar, S.K.; Myasnikov, A.G.; Kratzat, H.; Hazemann, I.; Klaholz, B. Visualization of chemical modifications in the human $80 \mathrm{~S}$ ribosome structure. Nature 2017, 551, 472-477. [CrossRef] [PubMed]

3. Taoka, M.; Nobe, Y.; Yamaki, Y.; Sato, K.; Ishikawa, H.; Izumikawa, K.; Yamauchi, Y.; Hirota, K.; Nakayama, H.; Takahash, N.; et al. Landscape of the complete RNA chemical modifications in the human $80 \mathrm{~S}$ ribosome. Nucleic Acids Res. 2018, 46, 9289-9298. [CrossRef] [PubMed]

4. Pletnev, P.; Guseva, E.; Zanina, A.; Evfratov, S.; Dzama, M.; Treshin, V.; Pogorel'Skaya, A.; Osterman, I.; Golovina, A.; Rubtsova, M.; et al. Comprehensive Functional Analysis of Escherichia coli Ribosomal RNA Methyltransferases. Front. Genet. 2020, 11, 97. [CrossRef]

5. Kiss-László, Z.; Henry, Y.; Bachellerie, J.-P.; Caizergues-Ferrer, M.; Kiss, T. Site-specific ribose methylation of preribosomal RNA: A novel function for small nucleolar RNAs. Cell 1996, 85, 1077-1088. [CrossRef]

6. Jeppesen, C.; Stebbins-Boaz, B.; Gerbi, S.A. Nucleotide sequence determination and secondary structure of Xenopus U3 snRNA. Nucleic Acids Res. 1988, 16, 2127-2148. [CrossRef]

7. Hughes, J.M.; Konings, D.A.; Cesareni, G. The yeast homologue of U3 snRNA. EMBO J. 1987, 6, $2145-2155$. [CrossRef]

8. Porter, G.L.; Brennwald, P.J.; Holm, K.A.; Wise, J.A. The sequence of U3 from Schizosaccharomyces pombe suggests structural divergence of this snRNA between metazoans and unicellular eukaryotes. Nucleic Acids Res. 1988, 16, 10131-10152. [CrossRef]

9. Tyc, K. and J.A. Steitz, U3, U8 and U13 comprise a new class of mammalian snRNPs localized in the cell nucleolus. EMBO J. 1989, 8, 3113-3119. [CrossRef]

10. Klein, D.; Schmeing, T.; Moore, P.; Steitz, T. The kink-turn: A new RNA secondary structure motif. EMBO J. 2001, 20, 4214-4221. [CrossRef]

11. Watkins, N.J.; Dickmanns, A.; Luhrmann, R. Conserved stem II of the box C/D motif is essential for nucleolar localization and is required, along with the $15.5 \mathrm{~K}$ protein, for the hierarchical assembly of the box C/D snoRNP. Mol. Cell. Biol. 2002, 22, 8342-8352. [CrossRef] [PubMed]

12. Tollervey, D.; Lehtonen, H.; Jansen, R.; Kern, H.; Hurt, E.C. Temperature-sensitive mutations demonstrate roles for yeast fibrillarin in pre-rRNA processing, pre-rRNA methylation, and ribosome assembly. Cell 1993, 72, 443-457. [CrossRef]

13. Christensen, M.E.; Beyer, A.L.; Walker, B.; LeStourgeon, W.M. Identification of NG, NG-dimethylarginine in a nuclear protein from the lower eukaryote physarum polycephalum homologous to the major proteins of mammalian $40 S$ ribonucleoprotein particles. Biochem. Biophys. Res. Commun. 1977, 74, 621-629. [CrossRef]

14. Ochs, R.L.; Lischwe, M.A.; Spohn, W.H.; Busch, H. Fibrillarin: A new protein of the nucleolus identified by autoimmune sera. Biol. Cell 1985, 54, 123-133. [CrossRef] [PubMed]

15. Jansen, R.; Tollervey, D.; Hurt, E.C. A U3 snoRNP protein with homology to splicing factor PRP4 and G beta domains is required for ribosomal RNA processing. EMBO J. 1993, 12, 2549-2558. [CrossRef] [PubMed]

16. Watkins, N.; Ségault, V.; Charpentier, B.; Nottrott, S.; Fabrizio, P.; Bachi, A.; Wilm, M.; Rosbash, M.; Branlant, C.; Lührmann, R. A common core RNP structure shared between the small nucleoar box C/D RNPs and the spliceosomal U4 snRNP. Cell 2000, 103, 457-466. [CrossRef]

17. Nottrott, S.; Hartmuth, K.; Fabrizio, P.; Urlaub, H.; Vidović, I.; Ficner, R.; Lührmann, R. Functional interaction of a novel 15.5kD [U4/U6.U5] tri-snRNP protein with the 5' stem-loop of U4 snRNA. EMBO J. 1999, 18, 6119-6133. [CrossRef]

18. Vidovic, I.; Nottrott, S.; Hartmuth, K.; Lührmann, R.; Ficner, R. Crystal structure of the spliceosomal 15.5kD protein bound to a U4 snRNA fragment. Mol. Cell 2000, 6, 1331-1342. [CrossRef] 
19. Trinh-Rohlik, Q.; Maxwell, E.S. Homologous genes for mouse 4.5S hybRNA are found in all eukaryotes and their low molecular weight RNA transcripts intermolecularly hybridize with eukaryotic 18S ribosomal RNAs. Nucleic Acids Res. 1988, 16, 6041-6056. [CrossRef]

20. Qu, L.H.; Henry, Y.; Nicoloso, M.; Michot, B.; Azum, M.C.; Renalier, M.H.; Caizergues-Ferrer, M.; Bachellerie, J.P. U24, a novel intron-encoded small nucleolar RNA with two 12 nt long, phylogenetically conserved complementarities to $28 \mathrm{~S}$ rRNA. Nucleic Acids Res. 1995, 23, 2669-2676. [CrossRef]

21. Nicoloso, M.; Qu, L.H.; Michot, B.; Bachellerie, J.P. Intron-encoded, antisense small nucleolar RNAs: The characterization of nine novel species points to their direct role as guides for the 2'-O-ribose methylation of rRNAs. J. Mol. Biol 1996, 260, 178-195. [CrossRef] [PubMed]

22. Qu, L.-H.; Nicoloso, M.; Michot, B.; Azum, M.-C.; Caizergues-Ferrer, M.; Renalier, M.-H.; Bachellerie, J.-P. U21, a novel small nucleolar RNA with a $13 \mathrm{nt}$. complementarity to $28 \mathrm{~S}$ rRA, is encoded in an intron of ribosomal protein L5 gene in chicken and mammals. Nucleic Acids Res. 1994, 22, 4073-4081. [CrossRef] [PubMed]

23. Bachellerie, J.-P.; Michot, B.; Nicoloso, M.; Balakin, A.; Ni, J.; Fournier, M.J. Antisense snoRNAs: A family of nucleolar RNAs with long complementarities to rRNA. Trends Biochem. Sci. 1995, 20, 261-264. [CrossRef]

24. Cavaille, J.; Nicoloso, M.; Bachellerie, J.P. Targeted ribose methylation of RNA in vivo directed by tailored antisense RNA guides. Nature 1996, 383, 732-735. [CrossRef]

25. Tycowski, K.T.; Smith, C.M.; Shu, M.-D.; Steitz, J.A. A small nucleolar RNA requirement for site-specific ribose methylation of rRNA in Xenopus. Proc. Natl. Acad. Sci. USA 1996, 93, 14480-14485. [CrossRef]

26. Kiss-Laszlo, Z.; Henry, Y.; Kiss, T. Sequence and structural elements of methylation guide snoRNAs essential for site-specific ribose methylation of pre-rRNA. EMBO J. 1998, 17, 797-807. [CrossRef]

27. Lin, J.; Lai, S.; Jia, R.; Xu, A.; Zhang, L.; Lu, J.; Ye, K. Structural basis for site-specific ribose methylation by box C/D RNA protein complexes. Nature 2011, 469, 559-563. [CrossRef]

28. Ganot, P.; Bortolin, M.L.; Kiss, T. Site-specific pseudouridine formation in preribosomal RNA is guided by small nucleolar RNAs. Cell 1997, 89, 799-809. [CrossRef]

29. Ni, J.; Tien, A.L.; Fournier, M.J. Small nucleolar RNAs direct site-specific synthesis of pseudouridine in ribosomal RNA. Cell 1997, 89, 565-573. [CrossRef]

30. Balakin, A.G.; Smith, L.; Fournier, M.J. The RNA world of the nucleolus: Two major families of small RNAs defined by different box elements with related functions. Cell 1996, 86, 823-834. [CrossRef]

31. Ganot, P.; Caizergues-Ferrer, M.; Kiss, T. The family of box ACA small nucleolar RNAs is defined by an evolutionarily conserved secondary structure and ubiquitous sequence elements essential for RNA accumulation. Genes. Dev. 1997, 11, 941-956. [CrossRef] [PubMed]

32. Bortolin, M.L.; Ganot, P.; Kiss, T. Elements essential for accumulation and function of small nucleolar RNAs directing site-specific pseudouridylation of ribosomal RNAs. EMBO J. 1999, 18, 457-469. [CrossRef] [PubMed]

33. De Zoysa, M.D.; Wu, G.; Katz, R.; Yu, Y.-T. Guide-substrate base-pairing requirement for box H/ACA RNA-guided RNA pseudouridylation. RNA 2018, 24, 1106-1117. [CrossRef] [PubMed]

34. Kelly, E.K.; Czekay, D.P.; Kothe, U. Base-pairing interactions between substrate RNA and H/ACA guide RNA modulate the kinetics of pseudouridylation, but not the affinity of substrate binding by H/ACA small nucleolar ribonucleoproteins. RNA 2019, 25, 1393-1404. [CrossRef]

35. Girard, J.-P.; Lehtonen, H.; Caizergues-Ferrer, M.; Amalric, F.; Tollervey, D.; Lapeyre, B. GAR1 is an essential small nucleolar RNP protein required for pre-rRNA processing in yeast. EMBO J. 1992, 11, 673-682. [CrossRef]

36. Bousquet-Antonelli, C.; Henry, Y.; Gélugne, J.; Caizergues-Ferrer, M.; Kiss, T. A small nucleolar RNP protein is required for pseudouridylation of eukaryotic ribosomal RNAs. EMBO J. 1997, 16, 4770-4776. [CrossRef]

37. Lafontaine, D.L.; Bousquet-Antonelli, C.; Henry, Y.; Caizergues-Ferrer, M.; Tollervey, D. The box H + ACA snoRNAs carry Cbf5p, the putative rRNA pseudouridine synthase. Genes. Dev. 1998, 12, 527-537. [CrossRef]

38. Watkins, N.J.; Gottschalk, A.; Neubauer, G.; Kastner, B.; Fabrizio, P.; Mann, M.; Luehrmann, R. Cbf5p, a potential pseudouridine synthase, and Nhp2p, a putative RNA-binding protein, are present together with Gar1p in all H BOX/ACA-motif snoRNPs and constitute a common bipartite structure. RNA 1998, 4, 1549-1568. [CrossRef] 
39. Henras, A.; Henry, Y.; Bousquet-Antonelli, C.; Noaillac-Depeyre, J.; Gélugne, J.P.; Caizergues-Ferrer, M. Nhp2p and Nop10p are essential for the function of H/ACA snoRNPs. EMBO J. 1998, 17, 7078-7090. [CrossRef]

40. Caton, E.A.; Kelly, E.K.; Kamalampeta, R.; Kothe, U. Efficient RNA pseudouridylation by eukaryotic H/ACA ribonucleoproteins requires high affinity binding and correct positioning of guide RNA. Nucleic Acids Res. 2018, 46, 905-916. [CrossRef]

41. Qu, L.-H.; Henras, A.; Lu, Y.-J.; Zhou, H.; Zhou, W.-X.; Zhu, Y.-Q.; Zhao, J.; Henry, Y.; Caizergues-Ferrer, M.; Bachellerie, J.-P. Seven novel methylation guide small nucleolar RNAs are processed from a common polycistronic transcript by Rat1p and RNase III in yeast. Mol. Cell. Biol. 1999, 19, 1144-1158. [CrossRef] [PubMed]

42. Bosio, M.C.; Fermi, B.; Dieci, G. Transcriptional control of yeast ribosome biogenesis: A multifaceted role for general regulatory factors. Transcription 2017, 8, 254-260. [CrossRef] [PubMed]

43. Preti, M.; Ribeyre, C.; Pascali, C.; Bosio, M.C.; Cortelazzi, B.; Rougemont, J.; Guarnera, E.; Naef, F.; Shore, D.; Dieci, G. The telomere-binding protein Tbf1 demarcates snoRNA gene promoters in Saccharomyces cerevisiae. Mol. Cell 2010, 38, 614-620. [CrossRef] [PubMed]

44. Li, T.; Zhou, X.; Wang, X.; Zhu, D.; Zhang, Y. Identification and characterization of human snoRNA core promoters. Genomics 2010, 96, 50-56. [CrossRef]

45. Harismendy, O.; Gendrel, C.; Soularue, P.; Gidrol, X.; Sentenac, A.; Werner, M.; Lefebvre, O. Genome-wide location of yeast RNA polymerase III transcription machinery. EMBO J. 2003, 22, 4738-4747. [CrossRef]

46. Moqtaderi, Z.; Struhl, K. Genome-wide occupancy profile of the RNA polymerase III machinery in Saccharomyces cerevisiae reveals loci with incomplete transcription complexes. Mol. Cell Biol. 2004, 24, 4118-4127. [CrossRef]

47. Roberts, U.N.; Stewart, A.J.; Huff, J.; Cairns, B.R. The RNA polymerase III transcriptome revealed by genome-wide localization and activity-occupancy relationships. Proc. Natl. Acad. Sci. USA 2003, 100, 14695-14700. [CrossRef]

48. Ikegami, K.; Lieb, J.D. Integral nuclear pore proteins bind to Pol III-transcribed genes and are required for Pol III transcript processing in C. elegans. Mol. Cell 2013, 51, 840-849. [CrossRef]

49. Isogai, Y.; Takada, S.; Tjian, R.; Keleş, S. Novel TRF1/BRF target genes revealed by genome-wide analysis of Drosophila Pol III transcription. EMBO J. 2007, 26, 79-89. [CrossRef]

50. Hellung-Larsen, P.; Jensen, E.G.; Frederiksen, S. Effect of 5,6-dichloro-1-beta-D-ribofuranosylbenzimidazole on the synthesis of low molecular weight, RNA components. Biochem. Biophys. Res. Commun. 1981, 99, 1303-1310. [CrossRef]

51. Hellung-Larsen, P.; Kulamowicz, I.; Frederiksen, S. Synthesis of low molecular weight RNA components in cells with a temperature-sensitive polymerase II. Biochim. Biophys. Acta 1980, 609, 201-204. [CrossRef]

52. Chandrasekharappa, S.C.; Smith, J.H.; Eliceiri, G.L. Biosynthesis of small nuclear RNAs in human cells. J. Cell Physiol. 1983, 117, 169-174. [CrossRef] [PubMed]

53. Kiss, T.; Marshallsay, C.; Filipowicz, W. Alteration of the RNA polymerase specificity of U3 snRNA genes during evolution and in vitro. Cell 1991, 65, 517-526. [CrossRef]

54. Yuan, Y.; Reddy, R. 5' flanking sequences of human MRP/7-2 RNA gene are required and sufficient for the transcription by RNA polymerase III. Biochim. Biophys. Acta 1991, 1089, 33-39. [CrossRef]

55. Schmitt, M.E.; Clayton, D.A. Yeast site-specific ribonucleoprotein endoribonuclease MRP contains an RNA component homologous to mammalian RNase MRP RNA and essential for cell viability. Genes Dev. 1992, 6, 1975-1985. [CrossRef] [PubMed]

56. Kufel, J.; Grzechnik, P. Small Nucleolar RNAs Tell a Different Tale. Trends Genet. 2019, 35, 104-117. [CrossRef]

57. Steinmetz, E.J.; Conrad, N.K.; A Brow, D.; Corden, J.L. RNA-binding protein Nrd1 directs poly(A)-independent 3'-end formation of RNA polymerase II transcripts. Nature 2001, 413, 327-331. [CrossRef]

58. Grzechnik, P.; Gdula, M.R.; Proudfoot, N.J. Pcf11 orchestrates transcription termination pathways in yeast. Genes Dev. 2015, 29, 849-861. [CrossRef]

59. Van Hoof, A.; Lennertz, P.; Parker, R. Yeast exosome mutants accumulate 3'-extended polyadenylated forms of U4 small nuclear RNA and small nucleolar RNAs. Mol. Cell Biol. 2000, 20, 441-452. [CrossRef]

60. Chanfreau, G.; Legrain, P.; Jacquier, A. Yeast RNase III as a key processing enzyme in small nucleolar RNAs metabolism. J. Mol. Biol. 1998, 284, 975-988. [CrossRef] 
61. Lee, C.Y.; Lee, A.; Chanfreau, G. The roles of endonucleolytic cleavage and exonucleolytic digestion in the 5'-end processing of S. cerevisiae box C/D snoRNAs. RNA 2003, 9, 1362-1370. [CrossRef] [PubMed]

62. Grzechnik, P.; Szczepaniak, S.A.; Dhir, S.; Pastucha, A.; Parslow, H.; Matuszek, Z.; Mischo, H.E.; Kufel, J.; Proudfoot, N.J. Nuclear fate of yeast snoRNA is determined by co-transcriptional Rnt1 cleavage. Nat. Commun. 2018, 9, 1783. [CrossRef] [PubMed]

63. Liu, J.; Maxwell, E.S. Mouse U14 snRNA is encoded in an intron of the mouse cognate hsc70 heat shock gene. Nucleic Acids Res. 1990, 18, 6565-6571. [CrossRef] [PubMed]

64. Leverette, R.D.; Andrews, M.T.; Maxwell, E.S. Mouse U14 snRNA is a processed intron of the cognate hsc70 heat shock pre-messenger RNA. Cell 1992, 71, 1215-1221. [CrossRef]

65. Tycowski, K.T.; Shu, M.D.; Steitz, J.A. A small nucleolar RNA is processed from an intron of the human gene encoding ribosomal protein S3. Genes Dev. 1993, 7, 1176-1190. [CrossRef]

66. Bond, U.M.; Yario, T.A.; Steitz, J.A. Multiple processing-defective mutations in a mammalian histone pre-mRNA are suppressed by compensatory changes in U7 RNA both in vivo and in vitro. Genes Dev. 1991, 5, 1709-1722. [CrossRef]

67. Bizarro, J.; Charron, C.; Boulon, S.; Westman, B.; Pradet-Balade, B.; Vandermoere, F.; Chagot, M.-E.; Hallais, M.; Ahmad, Y.; Leonhardt, H.; et al. Proteomic and 3D structure analyses highlight the C/D box snoRNP assembly mechanism and its control. J. Cell Biol 2014, 207, 463-480. [CrossRef]

68. Tycowski, K.T.; Shu, M.D.; Steitz, J.A. A mammalian gene with introns instead of exons generating stable RNA products. Nature 1996, 379, 464-466. [CrossRef]

69. Smith, C.M.; Steitz, J.A. Classification of gas5 as a multi-small-nucleolar-RNA (snoRNA) host gene and a member of the 5 '-terminal oligopyrimidine gene family reveals common features of snoRNA host genes. Mol. Cell Biol. 1998, 18, 6897-6909. [CrossRef]

70. Goustin, A.S.; Thepsuwan, P.; Kosir, M.A.; Lipovich, L. The Growth-Arrest-Specific (GAS)-5 Long Non-Coding RNA: A Fascinating lncRNA Widely Expressed in Cancers. Noncoding RNA 2019, 5, 46. [CrossRef]

71. Pelczar, P.; Filipowicz, W. The host gene for intronic U17 small nucleolar RNAs in mammals has no protein-coding potential and is a member of the $5^{\prime}$-terminal oligopyrimidine gene family. Mol. Cell Biol. 1998, 18, 4509-4518. [CrossRef] [PubMed]

72. Bortolin, M.L.; Kiss, T. Human U19 intron-encoded snoRNA is processed from a long primary transcript that possesses little potential for protein coding. RNA 1998, 4, 445-454. [PubMed]

73. Tanaka, R.; Satoh, H.; Moriyama, M.; Satoh, K.; Morishita, Y.; Yoshida, S.; Watanabe, T.; Nakamura, Y.; Mori, S. Intronic U50 small-nucleolar-RNA (snoRNA) host gene of no protein-coding potential is mapped at the chromosome breakpoint t(3;6)(q27;q15) of human B-cell lymphoma. Genes Cells 2000, 5, 277-287. [CrossRef] [PubMed]

74. Thoreen, C.C.; Chantranupong, L.; Keys, H.R.; Wang, T.C.; Gray, N.S.; Sabatini, D.M. A unifying model for mTORC1-mediated regulation of mRNA translation. Nature 2012, 485, 109-113. [CrossRef] [PubMed]

75. Hirose, T.; Shu, M.D.; Steitz, J.A. Splicing-dependent and -independent modes of assembly for intron-encoded box C/D snoRNPs in mammalian cells. Mol. Cell 2003, 12, 113-123. [CrossRef]

76. Ooi, S.L.; Samarsky, D.A.; Fournier, M.J.; Boeke, J.D. Intronic snoRNA biosynthesis in Saccharomyces cerevisiae depends on the lariat-debranching enzyme: Intron length effects and activity of a precursor snoRNA. RNA 1998, 4, 1096-1110. [CrossRef]

77. Kiss, T.; Filipowicz, W. Exonucleolytic processing of small nucleolar RNAs from pre-mRNA introns. Genes Dev. 1995, 9, 1411-1424. [CrossRef]

78. Massenet, S.; Bertrand, E.; Verheggen, C. Assembly and trafficking of box C/D and H/ACA snoRNPs. RNA Biol. 2017, 14, 680-692. [CrossRef]

79. Zhao, R.; Davey, M.; Hsu, Y.-C.; Kaplanek, P.; Tong, A.; Parsons, A.B.; Krogan, N.; Cagney, G.; Mai, D.; Greenblatt, J.; et al. Navigating the chaperone network: An integrative map of physical and genetic interactions mediated by the hsp90 chaperone. Cell 2005, 120, 715-727. [CrossRef]

80. Te, J.; Jia, L.; Rogers, J.; Miller, A.; Hartson, S.D. Novel subunits of the mammalian Hsp90 signal transduction chaperone. J. Proteome Res. 2007, 6, 1963-1973. [CrossRef]

81. Zhao, R.; Kakihara, Y.; Gribun, A.; Huen, J.; Yang, G.; Khanna, M.; Costanzo, M.; Brost, R.L.; Boone, C.; Hughes, T.R. Molecular chaperone Hsp90 stabilizes Pih1/Nop17 to maintain R2TP complex activity that regulates snoRNA accumulation. J. Cell Biol. 2008, 180, 563-578. [CrossRef] [PubMed] 
82. King, T.H.; Decatur, W.A.; Bertrand, E.; Maxwell, E.S.; Fournier, M.J. A well-connected and conserved nucleoplasmic helicase is required for production of box C/D and H/ACA snoRNAs and localization of snoRNP proteins. Mol. Cell Biol. 2001, 21,7731-7746. [CrossRef] [PubMed]

83. Zebarjadian, Y.; King, T.; Fournier, M.J.; Clarke, L.; Carbon, J. Point mutations in yeast CBF5 can abolish in vivo pseudouridylation of rRNA. Mol. Cell Biol. 1999, 19, 7461-7472. [CrossRef] [PubMed]

84. Jack, K.; Bellodi, C.; Landry, R.M.; Niederer, R.O.; Meskauskas, A.; Musalgaonkar, S.; Kopmar, N.; Krasnykh, O.; Dean, A.M.; Thompson, S.; et al. rRNA pseudouridylation defects affect ribosomal ligand binding and translational fidelity from yeast to human cells. Mol. Cell 2011, 44, 660-666. [CrossRef]

85. Esguerra, J.; Warringer, J.; Blomberg, A. Functional importance of individual rRNA 2'-O-ribose methylations revealed by high-resolution phenotyping. RNA 2008, 14, 649-656. [CrossRef]

86. Tollervey, D.; Guthrie, C. Deletion of a yeast small nuclear RNA gene impairs growth. EMBO J. 1985, 4, 3873-3878. [CrossRef]

87. Tollervey, D. A yeast small nuclear RNA is required for normal processing of pre-ribosomal RNA. EMBO J. 1987, 6, 4169-4175. [CrossRef]

88. King, T.H.; Liu, B.; McCully, R.R.; Fournier, M.J. Ribosome structure and activity are altered in cells lacking snoRNPs that form pseudouridines in the peptidyl transferase center. Mol. Cell 2003, 11, 425-435. [CrossRef]

89. Bonnerot, C.; Pintard, L.; Lutfalla, G. Functional redundancy of Spb1p and a snR52-dependent mechanism for the 2'-O-ribose methylation of a conserved rRNA position in yeast. Mol. Cell 2003, 12, 1309-1315. [CrossRef]

90. Caldas, T.; Binet, E.; Bouloc, P.; Costa, A.; Desgres, J.; Richarme, G. The FtsJ/RrmJ heat shock protein of Escherichia coli is a $23 \mathrm{~S}$ ribosomal RNA methyltransferase. J. Biol. Chem. 2000, 275, 16414-16419. [CrossRef]

91. Ben-Shem, A.; De Loubresse, N.G.; Melnikov, S.; Jenner, L.; Yusupova, G.; Yusupov, M. The structure of the eukaryotic ribosome at 3.0 A resolution. Science 2011, 334, 1524-1529. [CrossRef] [PubMed]

92. Liang, X.H.; Liu, Q.; Fournier, M.J. rRNA modifications in an intersubunit bridge of the ribosome strongly affect both ribosome biogenesis and activity. Mol. Cell 2007, 28, 965-977. [CrossRef] [PubMed]

93. Liang, X.H.; Liu, Q.; Fournier, M.J. Loss of rRNA modifications in the decoding center of the ribosome impairs translation and strongly delays pre-rRNA processing. RNA 2009, 15, 1716-1728. [CrossRef] [PubMed]

94. Mullineux, S.T.; Lafontaine, D.L. Mapping the cleavage sites on mammalian pre-rRNAs: Where do we stand? Biochimie 2012, 94, 1521-1532. [CrossRef] [PubMed]

95. Lestrade, L.; Weber, M.J. snoRNA-LBME-db, a comprehensive database of human H/ACA and C/D box snoRNAs. Nucleic Acids Res. 2006, 34, D158-D162. [CrossRef]

96. Nakamura, T.; Prestayko, A.W.; Busch, H. Studies on nucleolar 4 to 6 S ribonucleic acid of Novikoff hepatoma cells. J. Biol. Chem. 1968, 243, 1368-1375.

97. Hodnett, J.L.; Busch, H. Isolation and characterization of uridylic acid-rich $7 \mathrm{~S}$ ribonucleic acid of rat liver nuclei. J. Biol. Chem. 1968, 243, 6334-6342.

98. Prestayko, A.W.; Tonato, M.; Busch, H. Low molecular weight RNA associated with 28 s nucleolar RNA. J. Mol. Biol. 1970, 47, 505-515. [CrossRef]

99. Weinberg, R.A.; Penman, S. Small molecular weight monodisperse nuclear RNA. J. Mol. Biol. 1968, 38, 289-304. [CrossRef]

100. Reddy, R.; Ro-Choi, T.S.; Henning, D.; Shibata, H.; Choi, Y.C.; Busch, H.H. Modified nucleosides of nuclear and nucleolar low molecular weight ribonucleic acid. J. Biol. Chem. 1972, 247, 7245-7250.

101. Stroke, I.L.; Weiner, A.M. Genes and pseudogenes for rat U3A and U3B small nuclear RNA. J. Mol. Biol. 1985, 184, 183-193. [CrossRef]

102. Suh, D.; Busch, H.; Reddy, R. Isolation and characterization of a human U3 small nucleolar RNA gene. Biochem. Biophys. Res. Commun. 1986, 137, 1133-1140. [CrossRef]

103. Calvet, J.P.; Pederson, T. Base-pairing interactions between small nuclear RNAs and nuclear RNA precursors as revealed by psoralen cross-linking in vivo. Cell 1981, 26 Pt 1, 363-370. [CrossRef]

104. Maser, R.L.; Calvet, J.P. U3 small nuclear RNA can be psoralen-cross-linked in vivo to the $5^{\prime}$ external transcribed spacer of pre-ribosomal-RNA. Proc. Natl. Acad. Sci. USA 1989, 86, 6523-6527. [CrossRef] [PubMed]

105. Beltrame, M.; Tollervey, D. Identification and functional analysis of two U3 binding sites on yeast pre-ribosomal RNA. EMBO J. 1992, 11, 1531-1542. [CrossRef]

106. Sun, Q.; Zhu, X.; Qi, J.; An, W.; Lan, P.; Tan, D.; Chen, R.; Wang, B.; Zheng, S.; Zhang, C. Molecular architecture of the $90 \mathrm{~S}$ small subunit pre-ribosome. Elife 2017, 6, e22086. [CrossRef] 
107. Crouch, R.J.; Kanaya, S.; Earl, P.L. A model for the involvement of the small nucleolar RNA (U3) in processing eukaryotic ribosomal RNA. Mol. Biol. Rep. 1983, 9, 75-78. [CrossRef]

108. Bachellerie, J.P.; Michot, B.; Raynal, F. Recognition signals for mouse pre-rRNA processing. A potential role for U3 nucleolar RNA. Mol. Biol. Rep. 1983, 9, 79-86. [CrossRef]

109. Tague, B.W.; Gerbi, S.A. Processing of the large rRNA precursor: Two proposed categories of RNA-RNA interactions in eukaryotes. J. Mol. Evol 1984, 20,362-367. [CrossRef]

110. Parker, K.A.; Steitz, J.A. Structural analysis of the human U3 ribonucleoprotein particle reveal a conserved sequence available for base pairing with pre-rRNA. Mol. Cell Biol. 1987, 7, 2899-2913. [CrossRef]

111. Kass, S.; Tyc, K.; Steitz, J.A.; Sollner-Webb, B. The U3 small nucleolar ribonucleoprotein functions in the first step of preribosomal RNA processing. Cell 1990, 60, 897-908. [CrossRef]

112. Savino, R.; Gerbi, S.A. In vivo disruption of Xenopus U3 snRNA affects ribosomal RNA processing. EMBO J. 1990, 9, 2299-2308. [CrossRef] [PubMed]

113. Hughes, J.M.; Ares, M., Jr. Depletion of U3 small nucleolar RNA inhibits cleavage in the $5^{\prime}$ external transcribed spacer of yeast pre-ribosomal RNA and impairs formation of $18 \mathrm{~S}$ ribosomal RNA. EMBO J. 1991, 10, 4231-4239. [CrossRef] [PubMed]

114. Tollervey, D.; Lehtonen, H.; Carmo-Fonseca, M.; Hurt, E.C. The small nucleolar RNP protein NOP1 (fibrillarin) is required for pre-rRNA processing in yeast. EMBO J. 1991, 10, 573-583. [CrossRef] [PubMed]

115. Lübben, B.; Marshallsay, C.; Rottmann, N.; Lührmann, R. Isolation of U3 snoRNP from CHO cells: A novel $55 \mathrm{kDa}$ protein binds to the central part of U3 snoRNA. Nucleic Acids Res. 1993, 21, 5377-5385. [CrossRef] [PubMed]

116. Venema, J.; Vos, H.; Faber, A.W.; Van Venrooij, W.J.; Raué, H.A. Yeast Rrp9p is an evolutionarily conserved U3 snoRNP protein essential for early pre-rRNA processing cleavages and requires box $\mathrm{C}$ for its association. RNA 2000, 6, 1660-1671. [CrossRef]

117. Clerget, G.; Bourguignon-Igel, V.; Marmier-Gourrier, N.; Rolland, N.; Wacheul, L.; Manival, X.; Charron, C.; Kufel, J.; Méreau, A.; Senty-Ségault, V.; et al. Synergistic defects in pre-rRNA processing from mutations in the U3-specific protein Rrp9 and U3 snoRNA. Nucleic Acids Res. 2020, 48, 3848-3868. [CrossRef]

118. Granneman, S.; Kudla, G.; Petfalski, E.; Tollervey, D. Identification of protein binding sites on U3 snoRNA and pre-rRNA by UV cross-linking and high-throughput analysis of cDNAs. Proc. Natl. Acad. Sci. USA 2009, 106, 9613-9618. [CrossRef]

119. Dunbar, D.A.; Wormsley, S.; Agentis, T.M.; Baserga, S.J. Mpp10p, a U3 small nucleolar ribonucleoprotein component required for pre-18S rRNA processing in yeast. Mol. Cell Biol. 1997, 17, 5803-5812. [CrossRef]

120. Dragon, F.; Gallagher, J.E.G.; Compagnone-Post, P.A.; Mitchell, B.M.; Porwancher, K.A.; Wehner, K.A.; Wormsley, S.; Settlage, R.E.; Shabanowitz, J.; Osheim, Y.; et al. A large nucleolar U3 ribonucleoprotein required for $18 S$ ribosomal RNA biogenesis. Nature 2002, 417, 967-970. [CrossRef]

121. Miller, O.L., Jr.; Beatty, B.R. Visualization of nucleolar genes. Science 1969, 164, 955-957. [CrossRef] [PubMed]

122. Mougey, E.B.; O’Reilly, M.; Osheim, Y.; Sollner-Webb, B.; Miller, O.L.; Beyer, A. The terminal balls characteristic of eukaryotic rRNA transcription units in chromatin spreads are rRNA processing complexes. Genes Dev. 1993, 7, 1609-1619. [CrossRef] [PubMed]

123. Kornprobst, M.; Turk, M.; Kellner, N.; Cheng, J.; Flemming, D.; Koš-Braun, I.; Koš, M.; Thoms, M.; Berninghausen, O.; Beckmann, R.; et al. Architecture of the 90S Pre-ribosome: A Structural View on the Birth of the Eukaryotic Ribosome. Cell 2016, 166, 380-393. [CrossRef] [PubMed]

124. Chaker-Margot, M.; Barandun, J.; Hunziker, M.; Klinge, S. Architecture of the yeast small subunit processome. Science 2017, 355, eaal1880. [CrossRef]

125. Barandun, J.; Chaker-Margot, M.; Hunziker, M.; Molloy, K.R.; Chait, B.T.; Klinge, S. The complete structure of the small-subunit processome. Nat. Struct. Mol. Biol. 2017, 24, 944-953. [CrossRef]

126. Cheng, J.; Kellner, N.; Berninghausen, O.; Hurt, E.; Beckmann, R. 3.2-A-resolution structure of the $90 \mathrm{~S}$ preribosome before A1 pre-rRNA cleavage. Nat. Struct. Mol. Biol. 2017, 24, 954-964. [CrossRef]

127. Goldfarb, K.C.; Cech, T.R. Targeted CRISPR disruption reveals a role for RNase MRP RNA in human preribosomal RNA processing. Genes Dev. 2017, 31, 59-71. [CrossRef]

128. Chang, D.D.; Clayton, D.A. A novel endoribonuclease cleaves at a priming site of mouse mitochondrial DNA replication. EMBO J. 1987, 6, 409-417. [CrossRef]

129. Chang, D.D.; Clayton, D.A. A mammalian mitochondrial RNA processing activity contains nucleus-encoded RNA. Science 1987, 235, 1178-1184. [CrossRef] 
130. Chang, D.D.; Clayton, D.A. Mouse RNAase MRP RNA is encoded by a nuclear gene and contains a decamer sequence complementary to a conserved region of mitochondrial RNA substrate. Cell 1989, 56, 131-139. [CrossRef]

131. Clayton, D.A. A nuclear function for RNase MRP. Proc. Natl. Acad. Sci. USA 1994, 91, 4615-4617. [CrossRef] [PubMed]

132. Topper, J.N.; Clayton, D.A. Characterization of human MRP/Th RNA and its nuclear gene: Full length MRP/Th RNA is an active endoribonuclease when assembled as an RNP. Nucleic Acids Res. 1990, 18, 793-799. [CrossRef] [PubMed]

133. Schmitt, M.E.; Bennett, J.L.; Dairaghi, D.J.; Clayton, D.A. Secondary structure of RNase MRP RNA as predicted by phylogenetic comparison. FASEB J. 1993, 7, 208-213. [CrossRef] [PubMed]

134. Walker, S.C.; Avis, J.M. A conserved element in the yeast RNase MRP RNA subunit can participate in a long-range base-pairing interaction. J. Mol. Biol. 2004, 341, 375-388. [CrossRef] [PubMed]

135. Lindahl, L.; Fretz, S.; Epps, N.; Zengel, J.M. Functional equivalence of hairpins in the RNA subunits of RNase MRP and RNase P in Saccharomyces cerevisiae. RNA 2000, 6, 653-658. [CrossRef]

136. Gold, H.; Topper, J.; Clayton, D.; Craft, J. The RNA processing enzyme RNase MRP is identical to the Th RNP and related to RNase P. Science 1989, 245, 1377-1380. [CrossRef]

137. Reddy, R.; Li, W.Y.; Henning, D.; Choi, Y.C.; Nohga, K.; Busch, H. Characterization and subcellular localization of 7-8 S RNAs of Novikoff hepatoma. J. Biol. Chem. 1981, 256, 8452-8457.

138. Hashimoto, C.; Steitz, J.A. Sequential association of nucleolar 7-2 RNA with two different autoantigens. J. Biol. Chem. 1983, 258, 1379-1382.

139. Reimer, G.; Raška, I.; Scheer, U.; Tan, E.M. Immunolocalization of 7-2-ribonucleoprotein in the granular component of the nucleolus. Exp. Cell Res. 1988, 176, 117-128. [CrossRef]

140. Lygerou, Z.; Allmang, C.; Tollervey, D.; Séraphin, B. Accurate processing of a eukaryotic precursor ribosomal RNA by ribonuclease MRP in vitro. Science 1996, 272, 268-270. [CrossRef]

141. Schmitt, M.E.; Clayton, D.A. Nuclear RNase MRP is required for correct processing of pre-5.8S rRNA in Saccharomyces cerevisiae. Mol. Cell Biol. 1993, 13, 7935-7941. [CrossRef] [PubMed]

142. Chu, S.; Archer, R.H.; Zengel, J.M.; Lindahl, L. The RNA of RNase MRP is required for normal processing of ribosomal RNA. Proc. Natl. Acad. Sci. USA 1994, 91, 659-663. [CrossRef] [PubMed]

143. Lindahl, L.; Archer, R.H.; Zengel, J.M. A new rRNA processing mutant of Saccharomyces cerevisiae. Nucleic Acids Res. 1992, 20, 295-301. [CrossRef] [PubMed]

144. Schmitt, M.E.; Clayton, D.A. Characterization of a unique protein component of yeast RNase MRP: An RNA-binding protein with a zinc-cluster domain. Genes Dev. 1994, 8, 2617-2628. [CrossRef]

145. Salinas, K.; Wierzbicki, S.; Zhou, L.; Schmitt, M.E. Characterization and purification of Saccharomyces cerevisiae RNase MRP reveals a new unique protein component. J. Biol. Chem. 2005, 280, 11352-11360. [CrossRef]

146. Reich, C.; Olsen, G.; Pace, B.; Pace, N. Role of the protein moiety of ribonuclease P, a ribonucleoprotein enzyme. Science 1988, 239, 178-181. [CrossRef]

147. Cai, T.; Aulds, J.; Gill, T.; Cerio, M.; E Schmitt, M. The Saccharomyces cerevisiae RNase mitochondrial RNA processing is critical for cell cycle progression at the end of mitosis. Genetics 2002, 161, 1029-1042.

148. Gill, T.; Cai, T.; Aulds, J.; Wierzbicki, S.; Schmitt, M.E. RNase MRP cleaves the CLB2 mRNA to promote cell cycle progression: Novel method of mRNA degradation. Mol. Cell Biol. 2004, 24, 945-953. [CrossRef]

149. Peculis, B.A.; Steitz, J.A. Disruption of U8 nucleolar snRNA inhibits $5.8 S$ and 28 S rRNA processing in the Xenopus oocyte. Cell 1993, 73, 1233-1245. [CrossRef]

150. Srivastava, L.; Lapik, Y.R.; Wang, M.; Pestov, D.G. Mammalian DEAD box protein Ddx51 acts in 3' end maturation of $28 \mathrm{~S}$ rRNA by promoting the release of U8 snoRNA. Mol. Cell Biol. 2010, 30, 2947-2956. [CrossRef]

151. Langhendries, J.-L.; Nicolas, E.; Doumont, G.; Goldman, S.; Lafontaine, D.L. The human box C/D snoRNAs U3 and U8 are required for pre-rRNA processing and tumorigenesis. Oncotarget 2016, 7, 59519-59534. [CrossRef] [PubMed]

152. Cote, C.A.; Greer, C.L.; Peculis, B.A. Dynamic conformational model for the role of ITS2 in pre-rRNA processing in yeast. RNA 2002, 8, 786-797. [PubMed] 
153. Cavaille, J.; Hadjiolov, A.A.; Bachellerie, J.P. Processing of mammalian rRNA precursors at the $3^{\prime}$ end of $18 \mathrm{~S}$ rRNA. Identification of cis-acting signals suggests the involvement of U13 small nucleolar RNA. Eur. J. Biochem. 1996, 242, 206-213. [CrossRef] [PubMed]

154. Ito, S.; Horikawa, S.; Suzuki, T.; Kawauchi, H.; Tanaka, Y.; Suzuki, T.; Suzuki, T. Human NAT10 is an ATP-dependent RNA acetyltransferase responsible for N4-acetylcytidine formation in $18 \mathrm{~S}$ ribosomal RNA (rRNA). J. Biol. Chem. 2014, 289, 35724-35730. [CrossRef]

155. Sharma, S.; Langhendries, J.L.; Watzinger, P.; Kötter, P.; Entian, K.D.; Lafontaine, D.L. Yeast Kre33 and human NAT10 are conserved 18S rRNA cytosine acetyltransferases that modify tRNAs assisted by the adaptor Tan1/THUMPD1. Nucleic Acids Res. 2015, 43, 2242-2258. [CrossRef]

156. Li, H.D.; Zagorski, J.; Fournier, M.J. Depletion of U14 small nuclear RNA (snR128) disrupts production of 18S rRNA in Saccharomyces cerevisiae. Mol. Cell Biol. 1990, 10, 1145-1152. [CrossRef]

157. Liang, W.Q.; Fournier, M.J. U14 base-pairs with 18S rRNA: A novel snoRNA interaction required for rRNA processing. Genes Dev. 1995, 9, 2433-2443. [CrossRef]

158. Samarsky, D.A.; Schneider, G.S.; Fournier, M.J. An essential domain in Saccharomyces cerevisiae U14 snoRNA is absent in vertebrates, but conserved in other yeasts. Nucleic Acids Res. 1996, 24, 2059-2066. [CrossRef]

159. Jarmolowski, A.; Zagorski, J.; Li, H.V.; Fournier, M.J. Identification of essential elements in U14 RNA of Saccharomyces cerevisiae. EMBO J. 1990, 9, 4503-4509. [CrossRef]

160. Dunbar, D.A.; Baserga, S.J. The U14 snoRNA is required for 2'-O-methylation of the pre- $18 \mathrm{~S}$ rRNA in Xenopus oocytes. RNA 1998, 4, 195-204.

161. Tycowski, K.T.; Shu, M.D.; Steitz, J.A. Requirement for intron-encoded U22 small nucleolar RNA in $18 S$ ribosomal RNA maturation. Science 1994, 266, 1558-1561. [CrossRef] [PubMed]

162. Enright, C.A.; Maxwell, E.S.; Eliceiri, G.L.; Sollner-Webb, B. 5’ETS rRNA processing facilitated by four small RNAs: U14, E3, U17, and U3. RNA 1996, 2, 1094-1099.

163. Atzorn, V.; Fragapane, P.; Kiss, T. U17/snR30 is a ubiquitous snoRNA with two conserved sequence motifs essential for 18S rRNA production. Mol. Cell Biol. 2004, 24, 1769-1778. [CrossRef] [PubMed]

164. Mishra, R.K.; Eliceiri, G.L. Three small nucleolar RNAs that are involved in ribosomal RNA precursor processing. Proc. Natl. Acad. Sci. USA 1997, 94, 4972-4977. [CrossRef] [PubMed]

165. Vaughan, M.H.; Soeiro, R.; Warner, J.R.; Darnell, J.E. The effects of methionine deprivation on ribosome synthesis in HeLa cells. Proc. Natl. Acad. Sci. USA 1967, 58, 1527-1534. [CrossRef] [PubMed]

166. Swann, P.F. The effect of ethionine on ribonucleic acid synthesis in rat liver. Biochem. J. 1975, 150, 335-344. [CrossRef]

167. Caboche, M.; Bachellerie, J.P. RNA methylation and control of eukaryotic RNA biosynthesis. Effects of cycloleucine, a specific inhibitor of methylation, on ribosomal RNA maturation. Eur. J. Biochem. 1977, 74, 19-29. [CrossRef]

168. Chelbi-Alix, M.K.; Expert-Bezançon, A.; Hayes, F.; Alix, J.H.; Branlant, C. Properties of ribosomes and ribosomal RNAs synthesized by Escherichia coli grown in the presence of ethionine. Normal maturation of ribosomal RNA in the absence of methylation. Eur. J. Biochem. 1981, 115, 627-634. [CrossRef]

169. Jiang, W.; Middleton, K.; Yoon, H.J.; Fouquet, C.; Carbon, J. An essential yeast protein, CBF5p, binds in vitro to centromeres and microtubules. Mol. Cell Biol. 1993, 13, 4884-4893. [CrossRef]

170. He, J.; Navarrete, S.; Jasinski, M.; Vulliamy, T.; Dokal, I.; Bessler, M.; Mason, P.J. Targeted disruption of Dkc1, the gene mutated in X-linked dyskeratosis congenita, causes embryonic lethality in mice. Oncogene 2002, 21, 7740-7744. [CrossRef]

171. Gu, B.-W.; Ge, J.; Fan, J.-M.; Bessler, M.; Mason, P.J. Slow growth and unstable ribosomal RNA lacking pseudouridine in mouse embryonic fibroblast cells expressing catalytically inactive dyskerin. FEBS Lett. 2013, 587, 2112-2117. [CrossRef] [PubMed]

172. Brand, R.C.; Klootwijk, J.; Planta, R.J.; Maden, B.E.H. Biosynthesis of a hypermodified nucleotide in Saccharomyces carlsbergensis $17 \mathrm{~S}$ and HeLa-cell $18 \mathrm{~S}$ ribosomal ribonucleic acid. Biochem. J. 1978, 169, 71-77. [CrossRef] [PubMed]

173. Elliott, B.A.; Ho, H.-T.; Ranganathan, S.V.; Vangaveti, S.; Ilkayeva, O.; Assi, H.A.; Choi, A.K.; Agris, P.F.; Holley, C. Modification of messenger RNA by 2'-O-methylation regulates gene expression in vivo. Nat. Commun. 2019, 10, 3401. [CrossRef] [PubMed]

174. Nostramo, R.T.; Hopper, A.K. Beyond rRNA and snRNA: tRNA as a 2'-O-methylation target for nucleolar and Cajal body box C/D RNPs. Genes Dev. 2019, 33, 739-740. [CrossRef] [PubMed] 
175. A McKusick, V.; Eldridge, R.; A Hostetler, J.; Ruangwit, U.; A Egeland, J. Dwarfism in the Amish. Ii. Cartilage-Hair Hypoplasia. Bull. Johns. Hopkins. Hosp. 1965, 116, 285-326.

176. Ridanpää, M.; Van Eenennaam, H.; Pelin, K.; Chadwick, R.; Johnson, C.; Yuan, B.; Vanvenrooij, W.; Pruijn, G.; Salmela, R.; Rockas, S.; et al. Mutations in the RNA component of RNase MRP cause a pleiotropic human disease, cartilage-hair hypoplasia. Cell 2001, 104, 195-203. [CrossRef]

177. Mattijssen, S.; Welting, T.J.; Pruijn, G.J. RNase MRP and disease. Wiley Interdiscip. Rev. RNA 2010, 1, $102-116$. [CrossRef]

178. Hermanns, P.; Bertuch, A.A.; Bertin, T.K.; Dawson, B.; Schmitt, M.E.; Shaw, C.A.; Zabel, B.; Lee, B. Consequences of mutations in the non-coding RMRP RNA in cartilage-hair hypoplasia. Hum. Mol. Genet. 2005, 14, 3723-3740. [CrossRef]

179. Dokal, I. Dyskeratosis congenita. Hematol. Am. Soc. Hematol. Educ. Program 2011, 2011, 480-486. [CrossRef]

180. Walne, A.J.; Vulliamy, T.; Marrone, A.; Beswick, R.; Kirwan, M.; Masunari, Y.; Al-Qurashi, F.-H.; Aljurf, M.; Dokal, I. Genetic heterogeneity in autosomal recessive dyskeratosis congenita with one subtype due to mutations in the telomerase-associated protein NOP10. Hum. Mol. Genet. 2007, 16, 1619-1629. [CrossRef]

181. Benyelles, M.; O’Donohue, M.-F.; Kermasson, L.; Lainey, E.; Borie, R.; Lagresle-Peyrou, C.; Nunes, H.; Cazelles, C.; Fourrage, C.; Ollivier, E.; et al. NHP2 deficiency impairs rRNA biogenesis and causes pulmonary fibrosis and Hoyeraal-Hreidarsson syndrome. Hum. Mol. Genet. 2020, 29, 907-922. [CrossRef] [PubMed]

182. Vulliamy, T.; Beswick, R.; Kirwan, M.; Marrone, A.; Digweed, M.; Walne, A.; Dokal, I. Mutations in the telomerase component NHP2 cause the premature ageing syndrome dyskeratosis congenita. Proc. Natl. Acad. Sci. USA 2008, 105, 8073-8078. [CrossRef] [PubMed]

183. Thumati, N.R.; Zeng, X.-L.; Au, H.H.T.; Jang, C.; Jan, E.; Wong, J.M. Severity of X-linked dyskeratosis congenita (DKCX) cellular defects is not directly related to dyskerin (DKC1) activity in ribosomal RNA biogenesis or mRNA translation. Hum. Mutat. 2013, 34, 1698-1707. [CrossRef] [PubMed]

184. Ruggero, D.; Shimamura, A. Marrow failure: A window into ribosome biology. Blood 2014, 124, $2784-2792$. [CrossRef]

185. Heiss, N.S.; Knight, S.W.; Vulliamy, T.; Klauck, S.M.; Wiemann, S.; Mason, P.J.; Poustka, A.; Dokal, I. X-linked dyskeratosis congenita is caused by mutations in a highly conserved gene with putative nucleolar functions. Nat. Genet. 1998, 19, 32-38. [CrossRef]

186. Mitchell, J.R.; Wood, E.; Collins, K. A telomerase component is defective in the human disease dyskeratosis congenita. Nature 1999, 402, 551-555. [CrossRef]

187. Ruggero, D.; Grisendi, S.; Piazza, F.; Rego, E.M.; Mari, F.; Rao, P.H.; Cordon-Cardo, C.; Pandolfi, P.P. Dyskeratosis congenita and cancer in mice deficient in ribosomal RNA modification. Science 2003, 299, 259-262. [CrossRef]

188. Yoon, A.; Peng, G.; Brandenburg, Y.; Zollo, O.; Xu, W.; Rego, E.; Ruggero, D. Impaired control of IRES-mediated translation in X-linked dyskeratosis congenita. Science 2006, 312, 902-906. [CrossRef]

189. Bellodi, C.; Kopmar, N.; Ruggero, D. Deregulation of oncogene-induced senescence and p53 translational control in X-linked dyskeratosis congenita. EMBO J. 2010, 29, 1865-1876. [CrossRef]

190. Bellodi, C.; McMahon, M.; Contreras, A.; Juliano, D.; Kopmar, N.; Nakamura, T.; Maltby, D.; Burlingame, A.; Savage, S.A.; Shimamura, A. H/ACA small RNA dysfunctions in disease reveal key roles for noncoding RNA modifications in hematopoietic stem cell differentiation. Cell Rep. 2013, 3, 1493-1502. [CrossRef]

191. Mills, E.W.; Green, R. Ribosomopathies: There's strength in numbers. Science 2017, 358. [CrossRef] [PubMed]

192. Nachmani, D.; Bothmer, A.H.; Grisendi, S.; Mele, A.; Bothmer, D.; Lee, J.D.; Monteleone, E.; Cheng, K.; Zhang, Y.; Bester, A.C.; et al. Germline NPM1 mutations lead to altered rRNA 2'-O-methylation and cause dyskeratosis congenita. Nat. Genet. 2019, 51, 1518-1529. [CrossRef] [PubMed]

193. Gee, H.; Buffa, F.M.; Camps, C.; Ramachandran, A.; Leek, R.; Taylor, M.; Patil, M.; Sheldon, H.; Betts, G.; Homer, J.; et al. The small-nucleolar RNAs commonly used for microRNA normalisation correlate with tumour pathology and prognosis. Br. J. Cancer 2011, 104, 1168-1177. [CrossRef] [PubMed]

194. Marcel, V.; Ghayad, S.E.; Belin, S.; Therizols, G.; Morel, A.-P.; Solano-Gonzàlez, E.; Vendrell, J.A.; Hacot, S.; Mertani, H.C.; Albaret, M.A.; et al. p53 acts as a safeguard of translational control by regulating fibrillarin and rRNA methylation in cancer. Cancer Cell 2013, 24, 318-330. [CrossRef]

195. Su, H.; Xu, T.; Ganapathy, S.; Shadfan, M.; Long, M.; Huang, T.H.-M.; Thompson, I.; Yuan, Z.-M. Elevated snoRNA biogenesis is essential in breast cancer. Oncogene 2014, 33, 1348-1358. [CrossRef] 
196. Valleron, W.; Laprevotte, E.; Gautier, E.-F.; Quelen, C.; Demur, C.; Delabesse, E.; Agirre, X.; Prosper, F.; Kiss, T.; Brousset, P. Specific small nucleolar RNA expression profiles in acute leukemia. Leukemia 2012, 26, 2052-2060. [CrossRef]

197. Mourtada-Maarabouni, M.; Pickard, M.R.; Hedge, V.L.; Farzaneh, F.; Williams, G. GAS5, a non-protein-coding RNA, controls apoptosis and is downregulated in breast cancer. Oncogene 2009, 28, 195-208. [CrossRef]

198. Dong, X.-Y.; Guo, P.; Boyd, J.; Sun, X.; Li, Q.; Zhou, W.; Dong, J.-T. Implication of snoRNA U50 in human breast cancer. J. Genet. Genom. 2009, 36, 447-454. [CrossRef]

199. Dong, X.-Y.; Rodriguez, C.; Guo, P.; Sun, X.; Talbot, J.T.; Zhou, W.; Petros, J.; Li, Q.; Vessella, R.L.; Kibel, A.S.; et al. SnoRNA U50 is a candidate tumor-suppressor gene at $6 \mathrm{q} 14.3$ with a mutation associated with clinically significant prostate cancer. Hum. Mol. Genet. 2008, 17, 1031-1042. [CrossRef]

200. Siprashvili, Z.; Webster, D.E.; Johnston, D.; Shenoy, R.M.; Ungewickell, A.J.; Bhaduri, A.; Flockhart, R.; Zarnegar, B.J.; Che, Y.; Meschi, F.; et al. The noncoding RNAs SNORD50A and SNORD50B bind K-Ras and are recurrently deleted in human cancer. Nat. Genet. 2016, 48, 53-58. [CrossRef]

201. McMahon, M.; Contreras, A.; Holm, M.; Uechi, T.; Forester, C.M.; Pang, X.; Jackson, C.; Calvert, M.E.; Chen, B.; Quigley, D.A.; et al. A single H/ACA small nucleolar RNA mediates tumor suppression downstream of oncogenic RAS. Elife 2019, 8.

202. Liang, J.; Wen, J.; Huang, Z.; Chen, X.-P.; Zhang, B.-X.; Chu, L. Small Nucleolar RNAs: Insight Into Their Function in Cancer. Front. Oncol. 2019, 9, 587. [CrossRef] [PubMed]

203. Thompson, D.M.; Lu, C.; Green, P.J.; Parker, R. tRNA cleavage is a conserved response to oxidative stress in eukaryotes. RNA 2008, 14, 2095-2103. [CrossRef] [PubMed]

204. Yamasaki, S.; Ivanov, P.; Hu, G.-F.; Anderson, P. Angiogenin cleaves tRNA and promotes stress-induced translational repression. J. Cell Biol. 2009, 185, 35-42. [CrossRef]

205. Fu, H.; Feng, J.; Liu, Q.; Sun, F.; Tie, Y.; Zhu, J.; Xing, R.; Sun, Z.; Zheng, X. Stress induces tRNA cleavage by angiogenin in mammalian cells. FEBS Lett. 2009, 583, 437-442. [CrossRef]

206. Haussecker, D.; Huang, Y.; Lau, A.; Parameswaran, P.; Fire, A.Z.; Kay, M.A. Human tRNA-derived small RNAs in the global regulation of RNA silencing. RNA 2010, 16, 673-695. [CrossRef]

207. Taft, R.J.; Glazov, E.A.; Lassmann, T.; Hayashizaki, Y.; Carninci, P.; Mattick, J. Small RNAs derived from snoRNAs. RNA 2009, 15, 1233-1240. [CrossRef]

208. Kishore, S.; Khanna, A.; Zhang, Z.; Hui, J.; Balwierz, P.; Stefan, M.; Beach, C.; Nicholls, R.D.; Zavolan, M.; Stamm, S. The snoRNA MBII-52 (SNORD 115) is processed into smaller RNAs and regulates alternative splicing. Hum. Mol. Genet. 2010, 19, 1153-1164. [CrossRef]

209. Mleczko, A.M.; Machtel, P.; Walkowiak, M.; Wasilewska, A.; Pietras, P.J.; Bąkowska-Żywicka, K. Levels of sdRNAs in cytoplasm and their association with ribosomes are dependent upon stress conditions but independent from snoRNA expression. Sci. Rep. 2019, 9, 18397. [CrossRef]

210. Lyons, S.; Achorn, C.; Kedersha, N.L.; Anderson, P.; Ivanov, P. YB-1 regulates tiRNA-induced Stress Granule formation but not translational repression. Nucleic Acids Res. 2016, 44, 6949-6960. [CrossRef]

211. Blenkiron, C.; Hurley, D.; Fitzgerald, S.; Print, C.; Lasham, A. Links between the oncoprotein YB-1 and small non-coding RNAs in breast cancer. PLoS ONE 2013, 8, e80171. [CrossRef] [PubMed]

212. Mordovkina, D.; Lyabin, D.; Smolin, E.; Sogorina, E.; Ovchinnikov, L.; Eliseeva, I. Y-Box Binding Proteins in mRNP Assembly, Translation, and Stability Control. Biomolecules 2020, 10, 591. [CrossRef] [PubMed]

213. Lyons, S.M.; Fay, M.M.; Ivanov, P. The role of RNA modifications in the regulation of tRNA cleavage. FEBS Lett. 2018, 592, 2828-2844. [CrossRef] [PubMed]

214. Kondrashov, N.; Pusic, A.; Stumpf, C.R.; Shimizu, K.; Hsieh, A.C.; Ishijima, J.; Shiroishi, T.; Barna, M. Ribosome-mediated specificity in Hox mRNA translation and vertebrate tissue patterning. Cell 2011, 145, 383-397. [CrossRef]

215. Birkedal, U.; Christensen-Dalsgaard, M.; Krogh, N.; Sabarinathan, R.; Gorodkin, J.; Nielsen, H. Profiling of ribose methylations in RNA by high-throughput sequencing. Angew. Chem. Int. Ed. Engl. 2015, 54, 451-455. [CrossRef]

216. Maden, B.E. Identification of the locations of the methyl groups in $18 \mathrm{~S}$ ribosomal RNA from Xenopus laevis and man. J. Mol. Biol. 1986, 189, 681-699. [CrossRef]

217. Maden, B.E. Locations of methyl groups in $28 \mathrm{~S}$ rRNA of Xenopus laevis and man. Clustering in the conserved core of molecule. J. Mol. Biol. 1988, 201, 289-314. [CrossRef]

218. Stanley, J.; Vassilenko, S. A different approach to RNA sequencing. Nature 1978, 274, 87-89. [CrossRef] 
219. Bakin, A.; Ofengand, J. A high sensitivity method for sequencing RNA: Application to ribosomal RNA. Biotechniques 1992, 13, 682-684.

220. Bakin, A.; Ofengand, J. Four newly located pseudouridylate residues in Escherichia coli 235 ribosomal RNA are all at the peptidyltransferase center: Analysis by the application of a new sequencing technique. Biochemistry 1993, 32, 9754-9762. [CrossRef]

221. Schaefer, M.; Kapoor, U.; Jantsch, M.F. Understanding RNA modifications: The promises and technological bottlenecks of the 'epitranscriptome'. Open. Biol. 2017, 7, 170077. [CrossRef]

222. Schwartz, S.; Motorin, Y. Next-generation sequencing technologies for detection of modified nucleotides in RNAs. RNA Biol. 2017, 14, 1124-1137. [CrossRef]

223. Helm, M.; Motorin, Y. Detecting RNA modifications in the epitranscriptome: Predict and validate. Nat. Rev. Genet. 2017, 18, 275-291. [CrossRef] [PubMed]

224. Li, X.; Xiong, X.; Yi, C. Epitranscriptome sequencing technologies: Decoding RNA modifications. Nat. Methods 2016, 14, 23-31. [CrossRef]

225. Vandivier, L.E.; Anderson, Z.D.; Gregory, B.D. HAMR: High-Throughput Annotation of Modified Ribonucleotides. Methods Mol. Biol. 2019, 1870, 51-67. [PubMed]

226. Vandivier, L.E.; Gregory, B.D. Reading the Epitranscriptome: New Techniques and Perspectives. Enzymes 2017, 41, 269-298. [PubMed]

227. Motorin, Y.; Marchand, V. Detection and Analysis of RNA Ribose 2'-O-Methylations: Challenges and Solutions. Genes (Basel) 2018, 9, 642. [CrossRef]

228. Incarnato, D.; Anselmi, F.; Morandi, E.; Neri, F.; Maldotti, M.; Rapelli, S.; Parlato, C.; Basile, G.; Oliviero, S. High-throughput single-base resolution mapping of RNA 2-O-methylated residues. Nucleic Acids Res. 2017, 45, 1433-1441. [CrossRef]

229. Zhu, Y.; Pirnie, S.P.; Carmichael, G.G. High-throughput and site-specific identification of 2'-O-methylation sites using ribose oxidation sequencing (RibOxi-seq). RNA 2017, 23, 1303-1314. [CrossRef]

230. Dai, Q.; Moshitch-Moshkovitz, S.; Han, D.; Kol, N.; Amariglio, N.; Rechavi, G.; Dominissini, D.; He, C. Nm-seq maps 2'-O-methylation sites in human mRNA with base precision. Nat. Methods 2017, 14, 695-698. [CrossRef]

231. Schwartz, S.; Bernstein, U.A.; Mumbach, M.; Jovanovic, M.; Herbst, R.H.; León-Ricardo, B.X.; Engreitz, J.M.; Guttman, M.; Satija, R.; Lander, E.S.; et al. Transcriptome-wide mapping reveals widespread dynamic-regulated pseudouridylation of ncRNA and mRNA. Cell 2014, 159, 148-162. [CrossRef] [PubMed]

232. Lovejoy, A.F.; Riordan, D.P.; Brown, P.O. Transcriptome-wide mapping of pseudouridines: Pseudouridine synthases modify specific mRNAs in S. cerevisiae. PLoS ONE 2014, 9, e110799. [CrossRef] [PubMed]

233. Carlile, T.M.; Rojas-Duran, M.F.; Zinshteyn, B.; Shin, H.; Bartoli, K.M.; Gilbert, W.V. Pseudouridine profiling reveals regulated mRNA pseudouridylation in yeast and human cells. Nature 2014, 515, 143-146. [CrossRef] [PubMed]

234. Sharma, S.; Marchand, V.; Motorin, Y.; Lafontaine, D.L.J. Identification of sites of 2'-O-methylation vulnerability in human ribosomal RNAs by systematic mapping. Sci. Rep. 2017, 7, 11490. [CrossRef] [PubMed]

235. Krogh, N.; Jansson, M.; Häfner, S.; Tehler, D.E.; Birkedal, U.; Christensen-Dalsgaard, M.; Lund, A.H.; Nielsen, $\mathrm{H}$. Profiling of 2'-O-Me in human rRNA reveals a subset of fractionally modified positions and provides evidence for ribosome heterogeneity. Nucleic Acids Res. 2016, 44, 7884-7895. [CrossRef] [PubMed]

236. Hebras, J.; Krogh, N.; Marty, V.; Nielsen, H.; Cavaillé, J. Developmental changes of rRNA ribose methylations in the mouse. RNA Biol. 2020, 17, 150-164. [CrossRef] [PubMed]

(C) 2020 by the authors. Licensee MDPI, Basel, Switzerland. This article is an open access article distributed under the terms and conditions of the Creative Commons Attribution (CC BY) license (http://creativecommons.org/licenses/by/4.0/). 